\title{
Hermann Karsten (1817-1908): a German naturalist in the Neotropics and the significance of his paleovertebrate collection
}

\author{
Jorge Domingo Carrillo-Briceño ${ }^{1}$, Eli Amson ${ }^{1,2}$, Alfredo Zurita ${ }^{3}$, and Marcelo Ricardo Sánchez-Villagra ${ }^{1}$ \\ ${ }^{1}$ Paleontological Institute and Museum, University of Zurich, Karl-Schmid-Strasse 4, Zürich, 8006, Switzerland \\ ${ }^{2}$ Humboldt-Universität, AG Morphologie und Formengeschichte, Bild Wissen Gestaltung - ein interdisziplinäres Labor \& \\ Institut für Biologie, Philippstraße, 12/13, 10115 Berlin, Germany \\ ${ }^{3}$ Centro de Ecología Aplicada del Litoral (CECOAL-CONICET) and Universidad Nacional del Nordeste, Ruta 5, km. 2,5, \\ 3400, Corrientes, Argentina
}

Correspondence to: Jorge Domingo Carrillo-Briceño (jorge.carrillo@ pim.uzh.ch, jorgedcb100@ gmail.com)

Received: 29 September 2016 - Revised: 18 November 2016 - Accepted: 19 November 2016 - Published: 12 December 2016

\begin{abstract}
During the mid-19th century, the German naturalist Hermann Karsten conducted a 12-year exploration (1844-1856) in the territories of Ecuador, New Granada (now Colombia) and Venezuela, allowing him to produce important botanic, geographic and geologic descriptions with valuable information that permits us to refer to him as a pioneer in many of these topics. With his return to Europe, abundant geological, paleontological and living plant specimens were brought and housed in European museums and botanical gardens. The Karsten collection included an important invertebrate collection from the Cretaceous of the Andes of Colombia and Venezuela, which was studied and published by himself and the renowned German paleontologist Leopold von Buch, filling a large void in the knowledge about ancients faunas. H. Karsten's vertebrate collection was never illustrated or subjected to a detailed taxonomic study, being mentioned in scientific publications in a repetitive manner and with incorrect taxonomic and provenance information. More than 160 years after they were collected, we carried out a taxonomic revision of all $\mathrm{H}$. Karsten's vertebrate specimens from Colombia and Venezuela, which are housed in the Museum of Natural History in Berlin. These specimens are represented by cranial and postcranial elements of megafauna, which include Megatheriidae, Mylodontidae and Glyptodontidae (Xenarthra), Toxodontidae (Notoungulata), Gomphotheriidae (Proboscidea), and many other indeterminate mammal remains. This revision is intended to clarify the taxonomy and provenance of the specimens, emphasizing the historical importance of this fossil collection and its significance for the paleontology of the region.
\end{abstract}

\section{Introduction}

Dr. Karl Hermann Gustav Wilhelm Karsten (1817-1908) (Fig. 1) was a Prussian naturalist from Stralsund (northern Germany), who, using his own economic resources, conducted a 12-year long exploration in the Neotropical territories of Venezuela (1844-1847 and 1848-1852) and the Republic of New Granada (now Colombia) and Ecuador (1852-1856) (Röhl, 1944; Alert, 1999). Alexander von Humboldt provided $\mathrm{H}$. Karsten with a letter of introduction to the Venezuelan president, requesting collaboration for the trips and intellectual aim of the young scientist (Röhl, 1944). The previous training of $\mathrm{H}$. Karsten as an apprentice in pharmacy and natural sciences was useful during his explorations in South America, which resulted in detailed descriptions of botany, entomology, geography and geology (Karsten, 1886; Röhl, 1944; Hedberg, 1974; Alert, 1999; Aalto, 2015). During his travels through Venezuela, New Granada and Ecuador, H. Karsten met well-known figures of the political, medical and the natural sciences, including Agustín Codazzi, Alexander Benitz, Karl Moritz, August Gottfried Knoche and Francisco José de Caldas; some of them shared long days of exploration and collection of specimens (Röhl, 1944; Tryon, 1963; Alert, 1999).

Hermann Karsten was engaged mainly in the study of tropical plants, which resulted in many publications, his best known work being Florae Columbiae Terrarumque Adiacentium Specimina Selecta in Peregrinatione Duodecim Annorum Observata Delineavit et Descripsit, published in two volumes from 1858 to 1869 (Tryon, 1963). Additionally, 


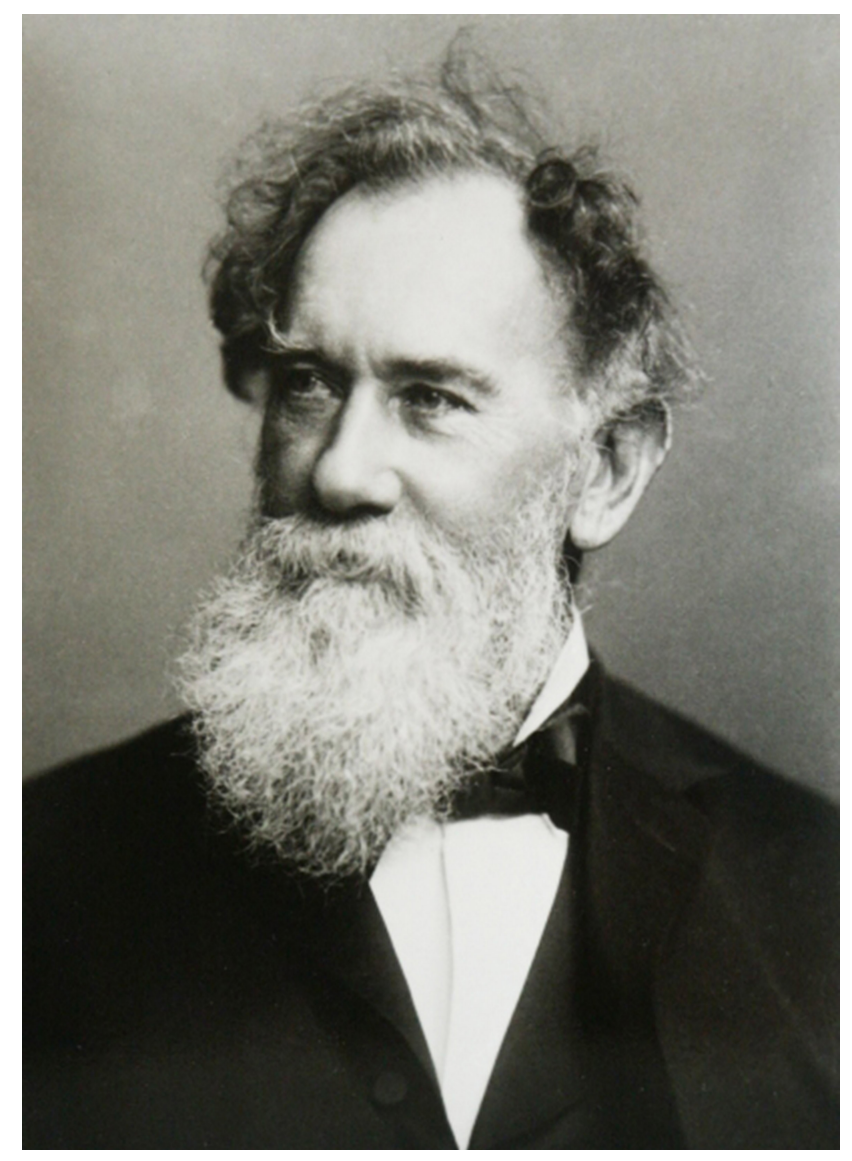

Figure 1. Portrait of Hermann Karsten. Picture courtesy of Stadtarchiv Schaffhausen (Biographien Sammlung der Naturforschenden Gesellschaft Schaffhausen), Switzerland.

H. Karsten was acquiring much geological information during his travels, especially about Cretaceous and Cenozoic rocks, observations and descriptions that are all the more remarkable because it is considered that he was primarily a botanist (Hedberg, 1974). His geological contributions (Venezuela, New Granada and Ecuador) included about 21 publications (summarized in Hedberg, 1974, 36-43), with valuable contributions on geomorphology, geological cartography, mineralogy, orogeny, paleontology, petrography and volcanology, among others subjects, Karsten being a regional pioneer in many of these topics. He published comments about the geology of the Island of Curaçao (Karsten, 1853), which he visited in the middle of his journey from Venezuela to New Granada in 1852. Thirty years after his return from South America, H. Karsten (1886) published his best-known geological contribution Géologie de l'ancienne Colombie bolivarienne: Vénézuela, Nouvelle-Grenade et Ecuador, a comprehensive summary of his geological results of 12 years of exploration. In this contribution, written in a diary style, H. Karsten reviewed previous geological, climatic, topographic/vegetation and soil observations, including many references to fossil finds (Karsten, 1886). In these and other publications (e.g., Karsten, 1849, 1858, 1886), Karsten also included many references to botanical and animal fossils. These fossils, especially invertebrates such as Cretaceous bivalves, echinoids and ammonites, were brought to and deposited in European museums, where some of them were studied by himself and by the renowned paleontologists Leopold von Buch and Charles Louis Perceval de Loriol (von Buch, 1850; Karsten, 1858, 1886; De Loriol, 1876). Using H. Karsten's specimens from the Andes of Lara, von Buch described for the first time a fossil species from Venezuela: Ammonites ( = Anapuzosia) tucuyensis (von Buch, 1850). Karsten (1851, pp. 445, 465) also mentioned the finding of amber in Venezuela, specifically from the states of Falcón and Lara; in the latter, he found abundant well-preserved fragments with embedded wasps and bees.

With regard to the fossil vertebrates, only allusive references were made by $\mathrm{H}$. Karsten to mammal remains from different locations in Venezuela, New Granada and Ecuador (e.g., Karsten, 1849, pp. 197, 199; 1851, pp. 465, 467, 479; 1859 b, p. 292 ; 1886 , pp. $11,14,20,29,32,44-45)$. According to H. Karsten, the mammalian fossils from Ecuador (Karsten, 1886, pp. 44-45) and some from New Granada (Karsten, 1886, pp. 32, 49) were found by other naturalists (e.g., Alexander von Humboldt, Andrés Posada-Arango and Theodor Wolf) prior to his expeditions. In H. Karsten's publication, there is also an enigmatic reference (without illustration or detailed stratigraphy and location) to the possible presence of Chirotherium, tracks in clay shales (ichnofossil) from the Cojedes and Guárico states, as well from the region between Mérida and Barinas (Andean region), all in Venezuela (Karsten, 1862, p. 286; 1886, pp. 13, 17). The H. Karsten vertebrate collection was never illustrated or subjected to a detailed taxonomic study. Moreover, many of $H$. Karsten's original fossil vertebrate specimens have been mentioned in scientific publications (especially in relation to Venezuelan paleontology) in a repetitive manner and sometimes with incorrect taxonomic and provenance information (e.g., Jahn, 1921, p. 39; Liddle, 1928, p. 351; Schaub, 1935, p. 1; Von der Osten, 1947, p. 161; Takacs et al., 1967, p. 32; Linares, 1983, p. 1; Ochsenius, 1980, p. 21; Rincón et al., 2006, p. 530, 2008, p. 197; Rincón and White, 2007, p. 2; Carrillo-Briceño et al., 2008, p. 242; Rincón, 2011, p. 894). More than 160 years after they were collected, we conducted a taxonomic revision of all $\mathrm{H}$. Karsten vertebrate fossils, also clarifying the provenance of specimens and discussing the historical importance of this collection.

\section{Materials and methods}

The H. Karsten vertebrate collection studied here is represented by a total of 60 cranial and postcranial elements of mammals (Table 1). All these specimens are housed at the Museum für Naturkunde in Berlin (MB.Ma.). In H. Karsten's publications, few fossil vertebrate remains corresponding to 
Table 1. Taxonomy of the fossil mammal specimens collected by H. Karsten.

\begin{tabular}{|c|c|c|c|c|c|c|c|c|}
\hline Superorder & Order & Family & Subfamily & Genus & Species & $\begin{array}{l}\text { Specimen } \\
\text { number }\end{array}$ & Element & Figure \\
\hline \multirow[t]{27}{*}{ Xenarthra } & Pilosa & Megatheriidae & Megatheriinae & Eremotherium & $\begin{array}{l}\text { Eremotherium } \\
\text { laurillardi }\end{array}$ & $\begin{array}{l}\text { MB.Ma. } \\
42937\end{array}$ & Right unciform & Fig. 3a-b \\
\hline & & & & cf. Eremotherium & $\begin{array}{l}\text { cf. Eremotherium } \\
\text { laurillardi }\end{array}$ & $\begin{array}{l}\text { MB.Ma. } \\
33534\end{array}$ & $\begin{array}{l}\text { Five molariforms }+ \\
\text { four fragments (in- } \\
\text { det. position) }\end{array}$ & Fig. $3 \mathrm{c}-\mathrm{m}$ \\
\hline & & & & cf. Eremotherium & $\begin{array}{l}\text { cf. Eremotherium } \\
\text { laurillardi }\end{array}$ & $\begin{array}{l}\text { MB.Ma. } \\
48085\end{array}$ & $\begin{array}{l}\text { Left humerus, } \\
\text { distal section }\end{array}$ & Fig. 3n \\
\hline & & & & cf. Eremotherium & $\begin{array}{l}\text { cf. Eremotherium } \\
\text { laurillardi }\end{array}$ & $\begin{array}{l}\text { MB.Ma. } \\
42903\end{array}$ & $\begin{array}{l}\text { Left tibia, distal } \\
\text { fragment }\end{array}$ & Fig. 3o-p \\
\hline & & & & cf. Eremotherium & $\begin{array}{l}\text { cf. Eremotherium } \\
\text { laurillardi }\end{array}$ & $\begin{array}{l}\text { MB.Ma. } \\
42936\end{array}$ & $\begin{array}{l}\text { Humeral head } \\
\text { (indet. laterality) }\end{array}$ & Fig. $3 q$ \\
\hline & & & & cf. Eremotherium & $\begin{array}{l}\text { cf. Eremotherium } \\
\text { laurillardi }\end{array}$ & $\begin{array}{l}\text { MB.Ma. } \\
42935\end{array}$ & $\begin{array}{l}\text { Right ulna, distal } \\
\text { fragment }\end{array}$ & Fig. 3r-s \\
\hline & & Mylodontidae & Mylodontinae & Indet. & Indet. & $\begin{array}{l}\text { MB.Ma. } \\
33535\end{array}$ & $\begin{array}{l}\text { Tooth (upper left } \\
\text { MF2) }\end{array}$ & Fig. $4 a-b$ \\
\hline & & Indet. & & Indet. & Indet. & $\begin{array}{l}\text { MB.Ma. } \\
42896\end{array}$ & $\begin{array}{l}\text { Left femur, distal } \\
\text { fragment }\end{array}$ & Fig. $4 c-d$ \\
\hline & & Indet. & & Indet. & Indet. & $\begin{array}{l}\text { MB.Ma. } \\
42897\end{array}$ & $\begin{array}{l}\text { Right tibia, distal } \\
\text { fragment }\end{array}$ & Fig. $4 \mathrm{e}-\mathrm{f}$ \\
\hline & & Indet. & & Indet. & Indet. & $\begin{array}{l}\text { MB.Ma. } \\
42905\end{array}$ & $\begin{array}{l}\text { Metapodial frag } \\
\text { ment (indet. } \\
\text { position) }\end{array}$ & Fig. $4 \mathrm{~g}-\mathrm{h}$ \\
\hline & & Indet. & & Indet. & Indet. & $\begin{array}{l}\text { MB.Ma. } \\
42902\end{array}$ & $\begin{array}{l}\text { Right ulna, proxi- } \\
\text { mal fragment }\end{array}$ & Fig. $4 \mathrm{i}-\mathrm{j}$ \\
\hline & & Indet. & & Indet. & Indet. & $\begin{array}{l}\text { MB.Ma. } \\
42901\end{array}$ & $\begin{array}{l}\text { Humeral head } \\
\text { (indet. laterality) }\end{array}$ & Fig. $4 \mathrm{k}$ \\
\hline & & Indet. & & Indet. & Indet. & $\begin{array}{l}\text { MB.Ma. } \\
33541\end{array}$ & $\begin{array}{l}\text { Ungual phalanx, } \\
\text { proximal fragment } \\
\text { (indet. position) }\end{array}$ & Fig. 4l-n \\
\hline & & Indet. & & Indet. & Indet. & $\begin{array}{l}\text { MB.Ma. } \\
17151\end{array}$ & $\begin{array}{l}\text { Left glenoid fossa, } \\
\text { scapula }\end{array}$ & Fig. $4 o-p$ \\
\hline & & Indet. & & Indet. & Indet. & $\begin{array}{l}\text { MB.Ma. } \\
33536\end{array}$ & $\begin{array}{l}\text { Proximal phalanx } \\
\text { (indet. position) }\end{array}$ & Fig. $4 q-r$ \\
\hline & & Indet. & & Indet. & Indet. & $\begin{array}{l}\text { MB.Ma. } \\
42900\end{array}$ & $\begin{array}{l}\text { Glenoid fossa, } \\
\text { scapula (indet. } \\
\text { laterality) }\end{array}$ & Fig. 5a-b \\
\hline & & Indet. & & Indet. & Indet. & $\begin{array}{l}\text { MB.Ma. } \\
33540\end{array}$ & Left? Magnum & Fig. $5 c-d$ \\
\hline & & Indet. & & Indet. & Indet. & $\begin{array}{l}\text { MB.Ma. } \\
42904\end{array}$ & Right astragalus & Fig. $5 \mathrm{e}-\mathrm{f}$ \\
\hline & & Indet. & & Indet. & Indet. & $\begin{array}{l}\text { MB.Ma. } \\
42907\end{array}$ & $\begin{array}{l}\text { Metatarsal V } \\
\text { (indet. laterality) }\end{array}$ & Fig. $5 \mathrm{~g}-\mathrm{h}$ \\
\hline & & Indet. & & Indet. & Indet. & $\begin{array}{l}\text { MB.Ma. } \\
42906\end{array}$ & Left metatarsal V & Fig. $5 \mathrm{i}-\mathrm{j}$ \\
\hline & & Indet. & & Indet. & Indet. & $\begin{array}{l}\text { MB.Ma. } \\
33537\end{array}$ & $\begin{array}{l}\text { Second phalanx } \\
\text { (indet. position) }\end{array}$ & Fig. $5 \mathrm{k}-\mathrm{l}$ \\
\hline & & Indet. & & Indet. & Indet. & $\begin{array}{l}\text { MB.Ma. } \\
33538\end{array}$ & $\begin{array}{l}\text { Metapodial, distal } \\
\text { fragment (indet. } \\
\text { position) }\end{array}$ & Fig. $5 m-n$ \\
\hline & & Indet. & & Indet. & Indet. & $\begin{array}{l}\text { MB.Ma. } \\
17154\end{array}$ & $\begin{array}{l}\text { Centrum, thoracic } \\
\text { vertebra }\end{array}$ & Fig. 6a-b \\
\hline & & Indet. & & Indet. & Indet. & $\begin{array}{l}\text { MB.Ma. } \\
17153\end{array}$ & $\begin{array}{l}\text { Centrum, thoracic } \\
\text { vertebra }\end{array}$ & Fig. $6 c-d$ \\
\hline & & Indet. & & Indet. & Indet. & $\begin{array}{l}\text { MB.Ma. } \\
17156\end{array}$ & $\begin{array}{l}\text { Centrum, thoracic } \\
\text { vertebra }\end{array}$ & Fig. 6e-f \\
\hline & & Indet. & & Indet. & Indet. & $\begin{array}{l}\text { MB.Ma. } \\
17155\end{array}$ & $\begin{array}{l}\text { Centrum, thoracic } \\
\text { vertebra }\end{array}$ & Fig. $6 \mathrm{~g}-\mathrm{h}$ \\
\hline & & Indet. & & Indet. & Indet. & $\begin{array}{l}\text { MB.Ma. } \\
33543\end{array}$ & $\begin{array}{l}\text { Centrum, caudal } \\
\text { vertebra }\end{array}$ & Fig. 6i-k \\
\hline
\end{tabular}


Table 1. Continued.

\begin{tabular}{|c|c|c|c|c|c|c|c|c|}
\hline Superorder & Order & Family & Subfamily & Genus & Species & $\begin{array}{l}\text { Specimen } \\
\text { number }\end{array}$ & Element & Figure \\
\hline & Cingulata & Glyptodontidae & & Glyptotherium & $\begin{array}{l}\text { Glyptotherium cf. } \\
\text { G. cylindricum }\end{array}$ & $\begin{array}{l}\text { MB.Ma. } \\
33532\end{array}$ & $\begin{array}{l}\text { Right } \\
\text { hemimandible, } \\
\text { and two upper } \\
\text { molariforms }\end{array}$ & Fig. 61-r \\
\hline & & & & Indet. & Indet. & $\begin{array}{l}\text { MB.Ma. } \\
\text { 33533-1 }\end{array}$ & Osteoderm & Fig. $6 \mathrm{~s}-\mathrm{t}$ \\
\hline & & & & Indet. & Indet. & $\begin{array}{l}\text { MB.Ma. } \\
\text { 33533-2-6 }\end{array}$ & $\begin{array}{l}\text { Four carpal- } \\
\text { metacarpal ele- } \\
\text { ments (indet. } \\
\text { laterality) }\end{array}$ & Fig. $6 \mathrm{u}-\mathrm{z}$ \\
\hline \multirow[t]{6}{*}{ Meridiungulata } & Notoungulata & Toxodontidae & Indet. & Indet. & Indet. & $\begin{array}{l}\text { MB.Ma. } \\
33517\end{array}$ & $\begin{array}{l}\text { Tooth frag- } \\
\text { ment? } \\
\text { (specimen not } \\
\text { found in the } \\
\text { collection) }\end{array}$ & Not figured \\
\hline & & & Indet. & Indet. & Indet. & $\begin{array}{l}\text { MB.Ma. } \\
33542\end{array}$ & $\begin{array}{l}\text { Pisiform bone } \\
\text { (indet. lateral- } \\
\text { ity) }\end{array}$ & Fig. $7 \mathrm{a}-\mathrm{d}$ \\
\hline & Proboscidea & Gomphotheriidae & Cuvieroniinae & Indet. & Indet. & $\begin{array}{l}\text { MB.Ma. } \\
17152\end{array}$ & $\begin{array}{l}\text { Thoracic } \\
\text { vertebra }\end{array}$ & Fig. 7e-g \\
\hline & & & & Indet. & Indet. & $\begin{array}{l}\text { MB.Ma. } \\
17146\end{array}$ & $\begin{array}{l}\text { Left metacarpal } \\
\text { II }\end{array}$ & Fig. $7 \mathrm{~h}-\mathrm{j}$ \\
\hline & & & & Indet. & Indet. & $\begin{array}{l}\text { MB.Ma. } \\
17147\end{array}$ & Right unciform & Fig. $7 \mathrm{k}-\mathrm{m}$ \\
\hline & & & & Indet. & Indet. & $\begin{array}{l}\text { MB.Ma. } \\
17148\end{array}$ & $\begin{array}{l}\text { Right } \\
\text { astragalus }\end{array}$ & Fig. $7 \mathrm{n}-\mathrm{o}$ \\
\hline \multirow[t]{10}{*}{ Mammalia Indet. } & & Indet. & & Indet. & Indet. & $\begin{array}{l}\text { MB.Ma. } \\
17150\end{array}$ & $\begin{array}{l}\text { Left humeral? } \\
\text { head }\end{array}$ & Fig. $7 p-q$ \\
\hline & & Indet. & & Indet. & Indet. & $\begin{array}{l}\text { MB.Ma. } \\
14109\end{array}$ & Femoral head & Fig. $7 r-s$ \\
\hline & & Indet. & & Indet. & Indet. & $\begin{array}{l}\text { MB.Ma. } \\
42899\end{array}$ & $\begin{array}{l}\text { Occipital } \\
\text { condyle }\end{array}$ & Fig. 8a-b \\
\hline & & Indet. & & Indet. & Indet. & $\begin{array}{l}\text { MB.Ma. } \\
42908\end{array}$ & $\begin{array}{l}\text { Centrum, } \\
\text { sacrum }\end{array}$ & Fig. 8c \\
\hline & & Indet. & & Indet. & Indet. & $\begin{array}{l}\text { MB.Ma. } \\
33539\end{array}$ & $\begin{array}{l}\text { Indet. fragmen- } \\
\text { tary postcranial } \\
\text { element }\end{array}$ & Fig. $8 d-f$ \\
\hline & & Indet. & & Indet. & Indet. & $\begin{array}{l}\text { MB.Ma. } \\
17145\end{array}$ & $\begin{array}{l}\text { Dorsal rib frag- } \\
\text { ments }\end{array}$ & Fig. $8 g-h$ \\
\hline & & Indet. & & Indet. & Indet. & $\begin{array}{l}\text { MB.Ma. } \\
17149\end{array}$ & $\begin{array}{l}\text { Dorsal rib frag- } \\
\text { ments }\end{array}$ & Fig. $8 \mathrm{i}$ \\
\hline & & Indet. & & Indet. & Indet. & $\begin{array}{l}\text { MB.Ma. } \\
42911\end{array}$ & $\begin{array}{l}\text { Indet. fragmen- } \\
\text { tary postcranial } \\
\text { element }\end{array}$ & Fig. $8 \mathrm{j}-\mathrm{k}$ \\
\hline & & Indet. & & Indet. & Indet. & $\begin{array}{l}\text { MB.Ma. } \\
42910\end{array}$ & $\begin{array}{l}\text { Indet. fragmen- } \\
\text { tary postcranial } \\
\text { element }\end{array}$ & Fig. 81 \\
\hline & & Indet. & & Indet. & Indet. & $\begin{array}{l}\text { MB.Ma. } \\
42909\end{array}$ & $\begin{array}{l}\text { Indet. fragmen- } \\
\text { tary postcranial } \\
\text { element }\end{array}$ & Fig. $8 m-n$ \\
\hline
\end{tabular}

his own find (among which are some references to the giant sloth Megatherium) were mentioned from different locations in Venezuela (Karsten, 1849, pp. 197, 199; 1851, pp. $465,467,479 ; 1859$ b, p. 292 ; 1886, pp. 11, 14, 20, 49) and Colombia (Karsten, 1851, p. 467; 1886, p. 49). In contrast, information mentioned in the MB.Ma. cata$\log$ about the H. Karsten vertebrate collection, which lacks a clear stratigraphic context, serves to identify only three localities in Venezuelan territory (Barbacoas, San Juan de Los Morros and Paraguaná Peninsula) and one in Colom- bia (Barbacoas-Candelillas District, Colombia) (Fig. 2, Table 2). Using H. Karsten's publications (1849, 1850a, b, $1851,1886)$ as a geographical reference, the Venezuelan localities (Table 2) are "Barbacoas town" $\left(9^{\circ} 49^{\prime} 34^{\prime \prime} \mathrm{N}\right.$, $\left.70^{\circ} 3^{\prime} 12^{\prime \prime} \mathrm{W}\right)$, Morán Municipality, Lara State; "San Juan

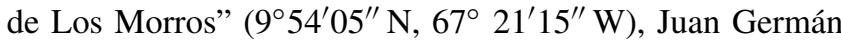
Roscio Municipality, Guárico State; and "Paraguaná Peninsula" ( $\left.11^{\circ} 56^{\prime} 41^{\prime \prime} \mathrm{N}, 69^{\circ} 55^{\prime} 23^{\prime \prime} \mathrm{W}\right)$, Falcón Municipality, Falcón State. The Colombian locality referred in the MB.Ma. catalog as "Barbacoas-Candelillas District, Kolumbien" is 


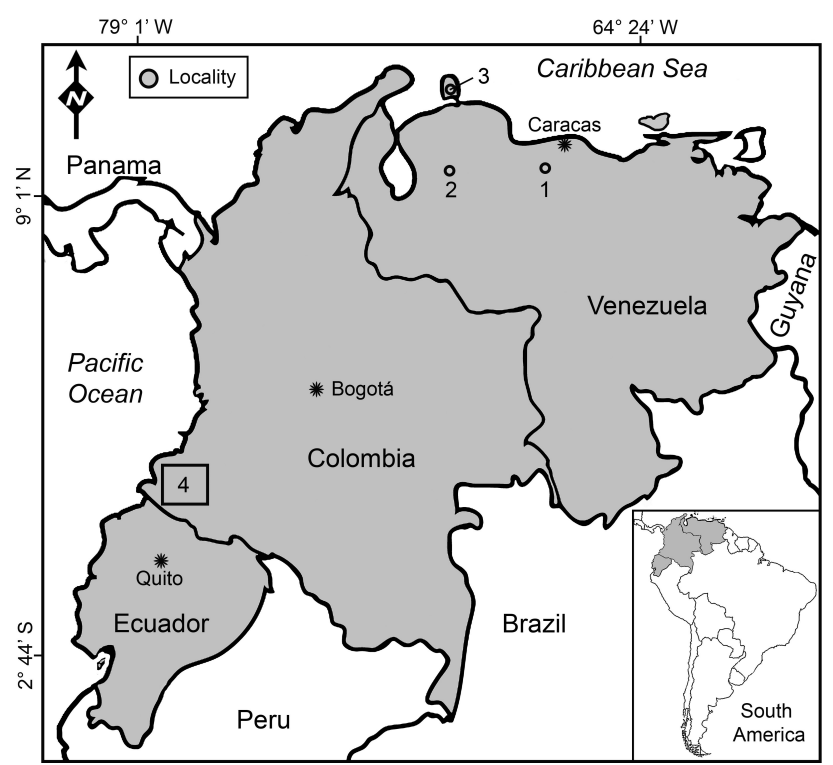

Figure 2. Map of the territories of Venezuela, Colombia (formerly, New Granada) and Ecuador visited by Hermann Karsten during his 12 years of explorations. The provenances of the fossil vertebrates discussed in this work are (1) San Juan de Los Morros; (2) Barbacoas; (3) Paraguaná Peninsula; (4) "Barbacoas-Candelillas District" locality (map shows possible location).

not referred to in any of the relevant publications (e.g., Karsten, 1853, 1858, 1859a, 1886). The most plausible explanation is that the "Barbacoas-Candelillas District" belonged to the ex-province of Barbacoas, which was founded in 1846 and ended in 1855, in the Republic of New Granada. Nowadays Barbacoas is a town on the banks of the Telembí River $\left(1^{\circ} 40^{\prime} 22^{\prime \prime} \mathrm{N}, 78^{\circ} 8^{\prime} 21^{\prime \prime} \mathrm{W}\right)$, in the Barbacoas Municipality, and Candelillas is a town on the banks of the Mira River $\left(1^{\circ} 28^{\prime} 32.51^{\prime \prime} \mathrm{N}, 78^{\circ} 41^{\prime} 8.57^{\prime \prime} \mathrm{W}\right)$, in the Tumaco Municipality; both belong to Nariño Department (southern Colombia). Although it is unknown if $\mathrm{H}$. Karsten was in any of these locations, it is well known that on his trip he visited many places in the current Nariño Department (e.g., Karsten, 1886, pp. 1-2, 22-35).

Taxonomic identification involved an extensive bibliographical review and comparative studies with collections such as the Centro de Investigaciones Antropológicas, Arqueológicas y Paleontológicas of the Universidad Experimental Francisco de Miranda (CIAAP, UNEFM-PF); the Museo de Ciencias de Caracas (MCNC) and the Universidad Central de Venezuela (UCV-VF), all in Venezuela; the Fossil Vertebrate Section of the Museum für Naturkunde, Berlin, Germany (MB.Ma.); the Palaeontological Institute and Museum at the University of Zurich (PIMUZ) and the Natural History Museum of Basel (NMB), Switzerland; the Museo de La Plata (MLP), Argentina; and the Muséum national d'Histoire naturelle, Paris, France.

\section{Hermann Karsten's fossil mammals}

The taxonomic composition of H. Karsten's fossil specimens includes 60 cranial and postcranial remains attributed to "ground sloths", large glyptodonts (close relatives of armadillos), "South American native ungulates", proboscideans and other indeterminate mammalian remains.

\section{1 "Ground sloths" (Xenarthra: Tardigrada Latham and Davies in Forster, 1795)}

The specimens ascribed to sloths (Tardigrada) are for the most part isolated and fragmentary elements (Tables 1-2), making precise taxonomic attributions difficult. It is noteworthy that all specimens represent large-sized taxa. At least two taxa belonging to two families, the Megatheriidae and the Mylodontidae, are represented (Table 1). One unciform (Fig. 3a-b) is characteristic of the megatheriine Eremotherium laurillardi (Lund, 1842) (see Cartelle and De Iuliis 1995). Various other postcranial and dental elements can safely be ascribed to a Megatheriinae, and we hence assign them to cf. Eremotherium laurillardi (Fig. 3c-s). A fragmentary isolated tooth (MB.Ma. 33535; Fig. 4a-b) is the only specimen safely ascribable to a Mylodontinae (likely cf. $M y$ lodon). Numerous other postcranial fragments are referred to Tardigrada indet. (Figs. 4c-r, 5a-n, 6a-k).

\subsection{Glyptodonts (Xenarthra: Cingulata Illiger 1811)}

The specimens are represented by a few cranial and postcranial elements (Fig. 61-z), all found in the San Juan de Los Morros locality (Tables 1-2). Cranial elements are represented by an anterior fragment of a right hemimandible (MB.Ma. 33532) preserving the molariforms 1-3 (Fig. 61-n), and two upper isolated molariforms (MB.Ma. 33532) corresponding to the two first (Mfs 1 and 2) (Fig. 6o-r). A comparison with complete material (e.g., MCNC s/n; see Carlini et al., 2008; Oliveira et al., 2010) shows that these remains from San Juan de Los Morros belong to Glyptotherium cf. G. cylindricum Brown, 1912. The mandible of $G$. cf. cylindricum is slender and morphologically similar to that of Glyptotherium texanum Osborn, 1903. It differs clearly from that of Glyptodon Owen, 1839, which has a greater robustness in this taxon. In turn, the preserved upper and lower molariforms are trilobate (Fig. 6o-r), as observed in the genus Glyptodon, and morphologically similar to that of Glyptotherium cylindricum. As in Glyptodon the molariforms show an asymmetric development of the three lobes, being more developed labially than lingually. With regard to the isolated postcranial elements, the osteoderm (MB.Ma. 3353-1) could correspond to an accessory osteoderm of the caudal border of the dorsal carapace or, alternatively, to the caudal rings of the caudal armor (Fig. 6st). Specimens MB.Ma. 3353-2-6 (Fig. 6u-z) correspond to carpal-metacarpal elements. However, the absence of diag- 
(a)

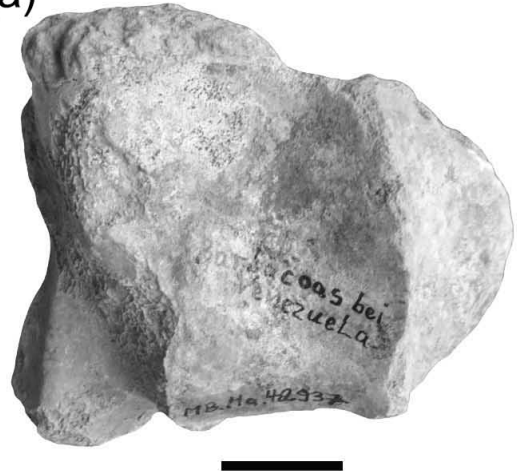

(b)

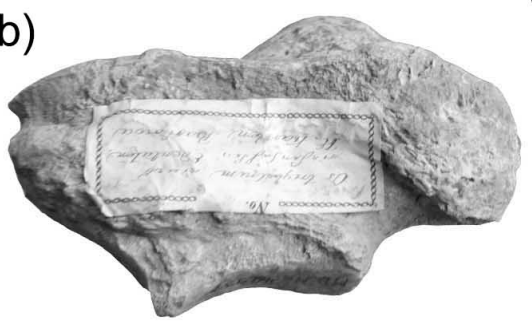

(c)

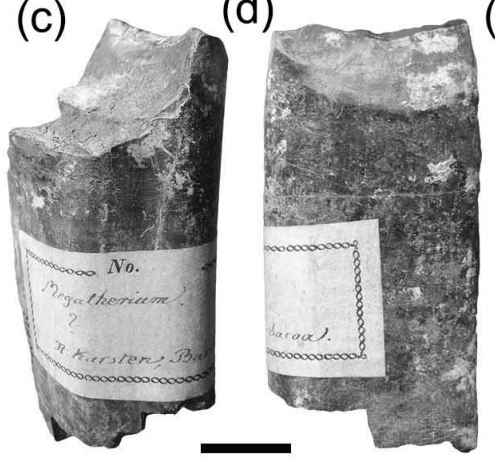

(g)

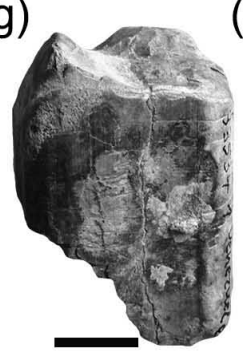

(h)

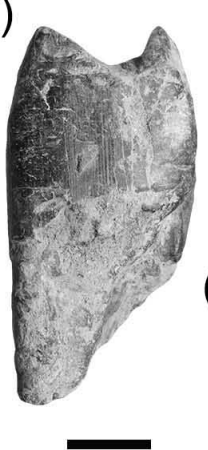

(n)
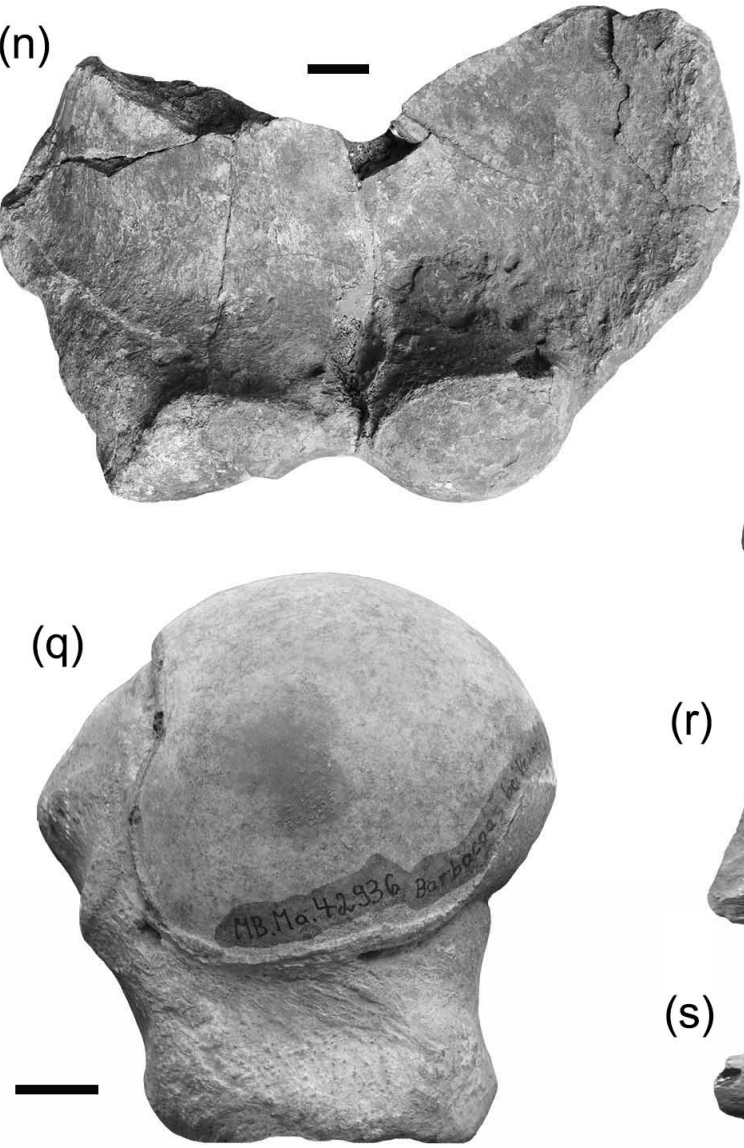

(o)

(r)

(s) (e)
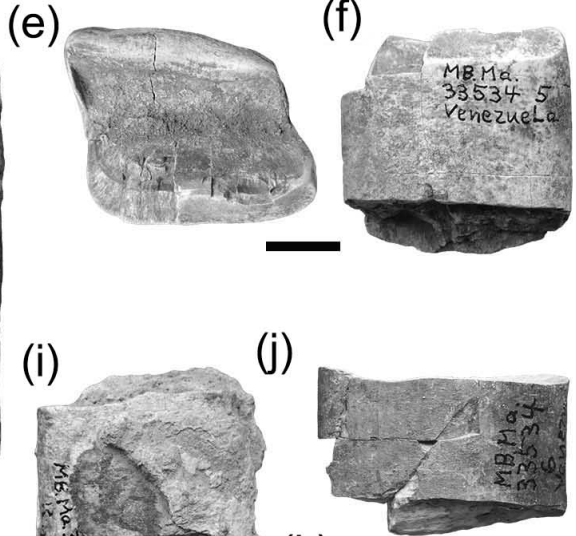

$(\mathrm{k})$

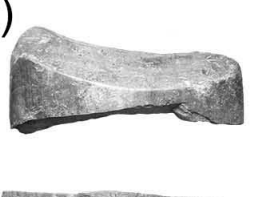

(m)
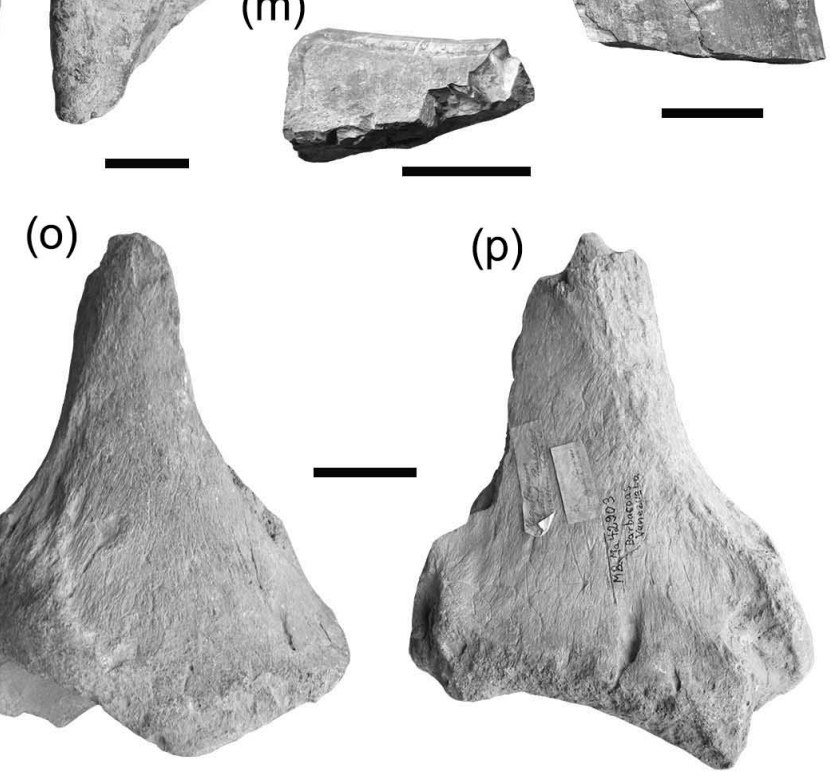

(p)

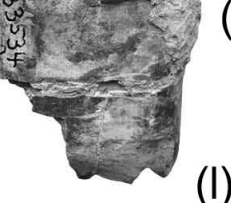

(l)
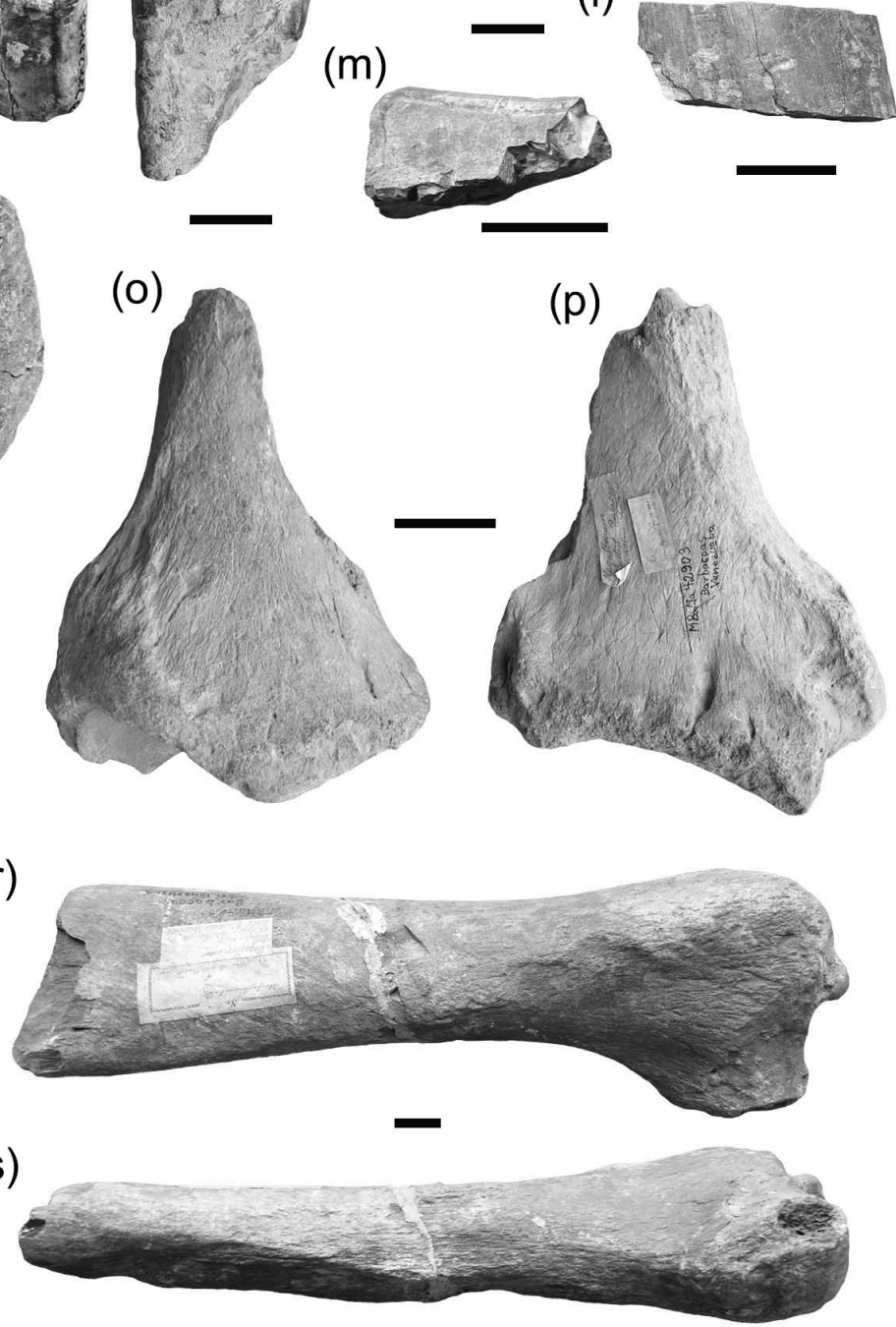

Figure 3. "Ground sloth" specimens. (a-b) Eremotherium laurillardi right unciform (MB.Ma. 42937) and (c-s) cf. Eremotherium laurillardi (c-m) Five fragmentary molariforms (MB.Ma. 33534); (n) distal fragment of left humerus, (MB.Ma. 48085); (o-p) distal fragment of left tibia (MB.Ma. 42903); (q) humeral head of indet. laterality (MB.Ma. 42936); (r-s) distal fragment of right ulna (MB.Ma. 42935). Scale bar equals $2 \mathrm{~cm}$. 
(a)

(b)
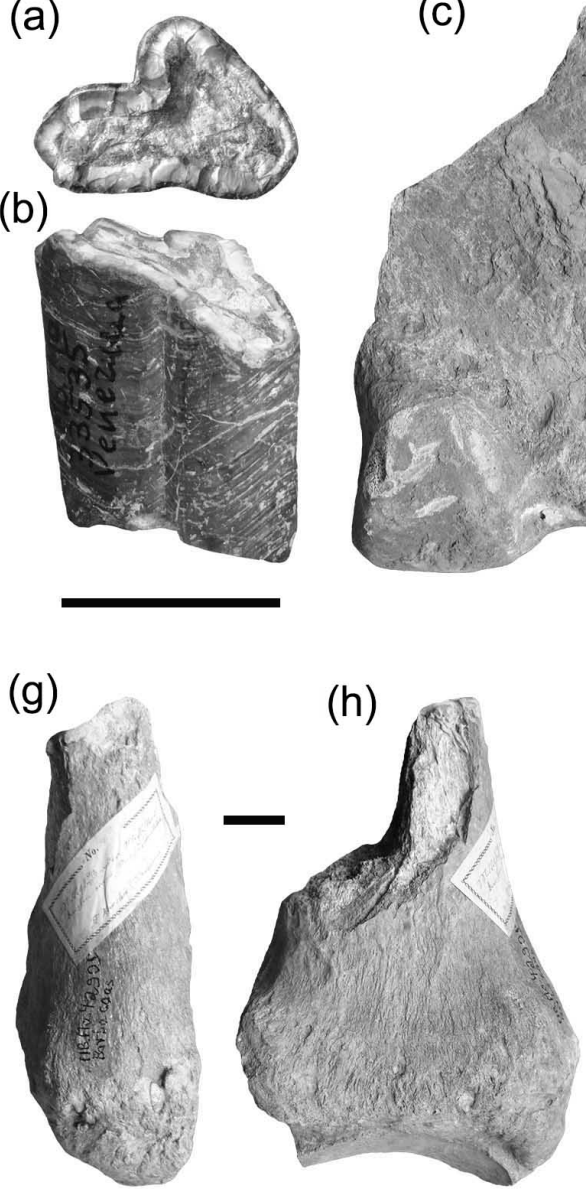

(g)

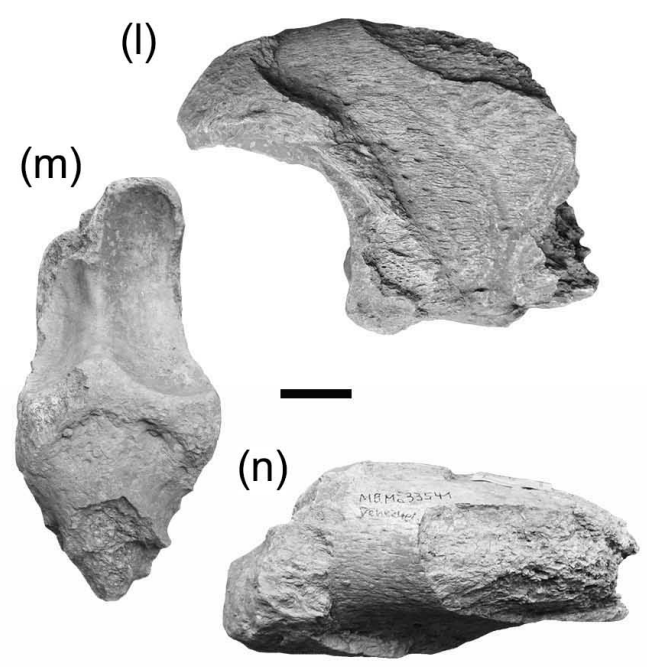

(i)

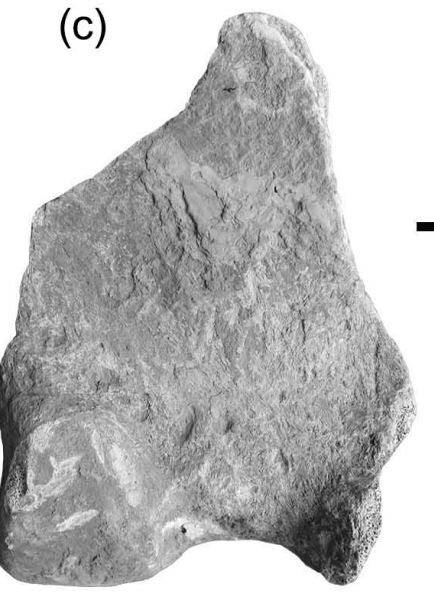

(d)
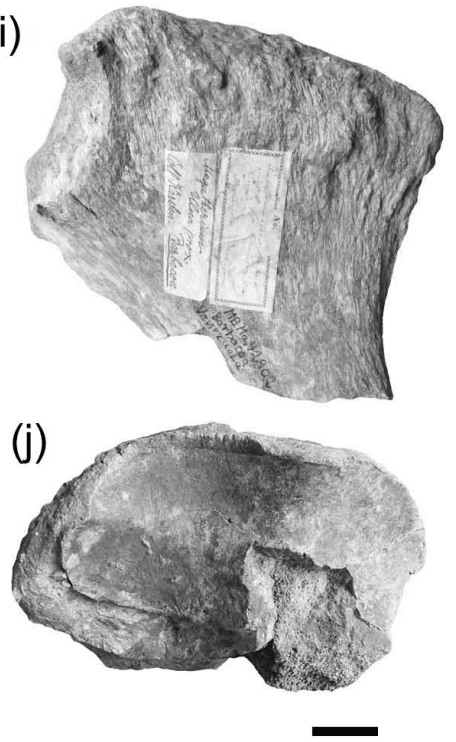

(d)

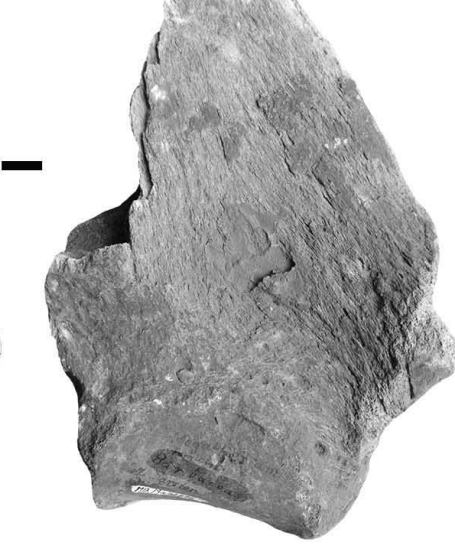

(f)

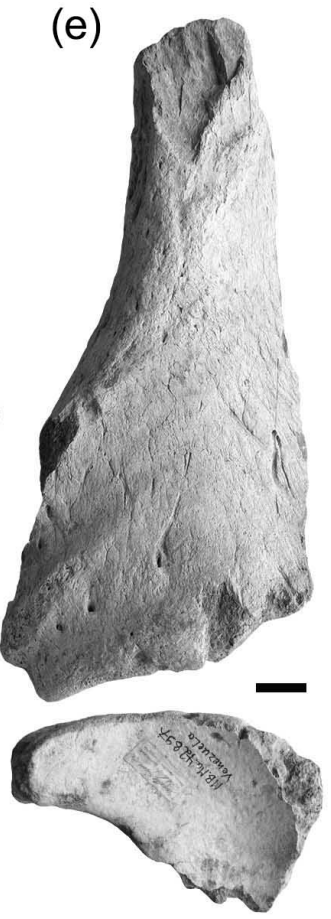

(k)

(o)

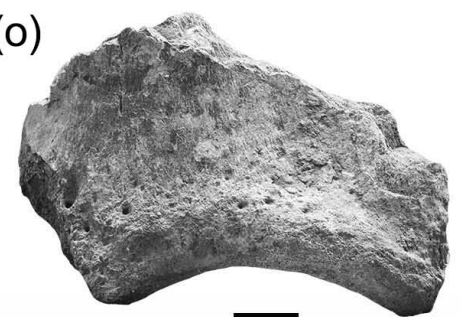

(p)

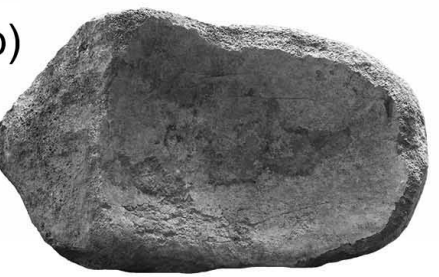

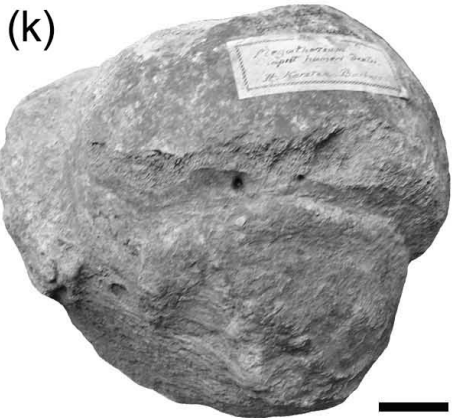

(q)

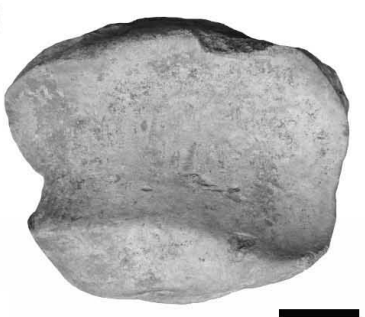

( $r)$

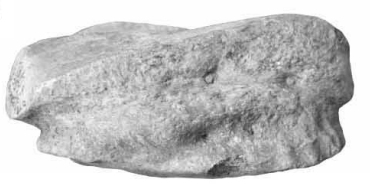

Figure 4. "Ground sloth" specimens. (a-b) Tooth of Mylodontinae indet. (MB.Ma. 33535) and (c-r) Tardigrada indet. c-d Distal fragment of left femur (MB.Ma. 42896); (e-f) distal fragment of right tibia (MB.Ma. 42897); (g-h) distal fragment of metapodial of indet. position (MB.Ma. 42905); (i-j) proximal fragment of right ulna (MB.Ma. 42902); (k) humeral head of indet. laterality (MB.Ma. 42901); (l-n) fragment of ungual phalanx (MB.Ma. 33541); (o-p) left glenoid fossa of scapula (MB.Ma. 17151); (q-r) proximal phalanx of indet. Position (MB.Ma. 33536). Scale bar equals $3 \mathrm{~cm}$. 

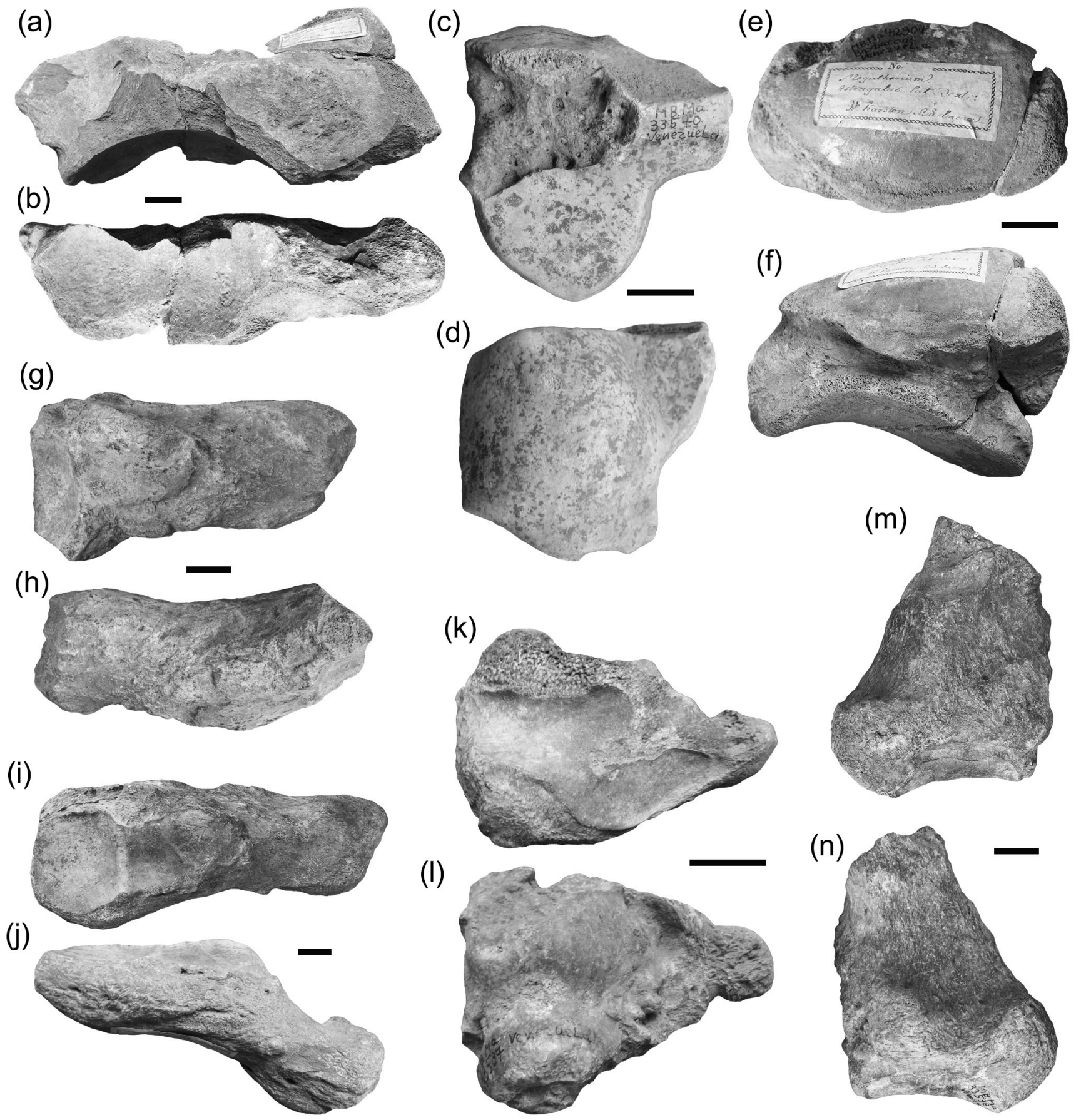

Figure 5. "Ground sloth" specimens. (a-n) Tardigrada indet. (a-b) Glenoid fossa of scapula (MB.Ma. 42900); (c-d) left? magnum (MB.Ma. 33540); (e-f) right astragalus (MB.Ma. 42904); (g-h) metatarsal V of indet. laterality (MB.Ma. 42907); (i-j) left metatarsal V (MB.Ma. 42906); (k-l) second phalanx of indet. laterality (MB.Ma. 33537); (m-n) distal fragment of metapodial of indet. laterality (MB.Ma. 33538). Scale bar equals $2 \mathrm{~cm}$. 
(a)

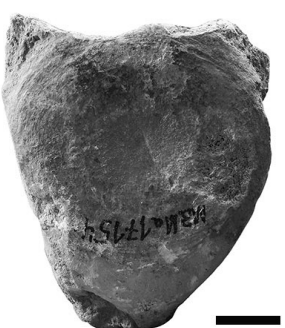

(b)

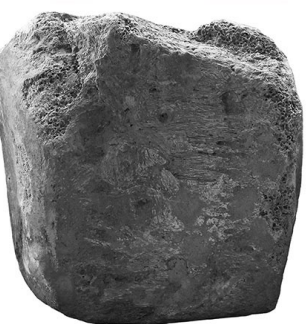

(i)

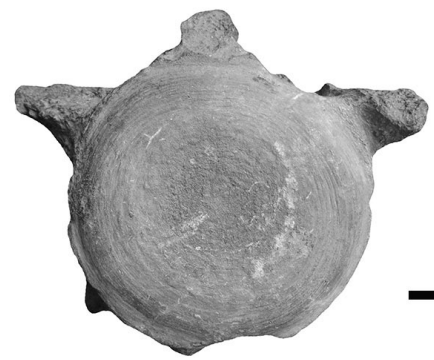

(c)

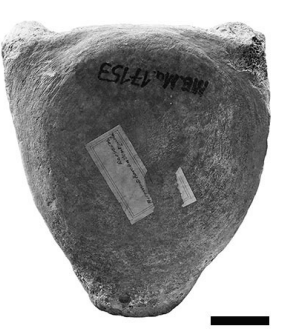

(d)

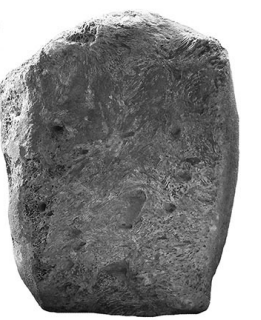

(e)

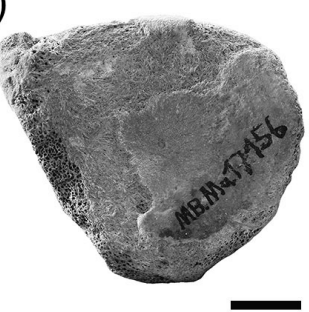

(f)

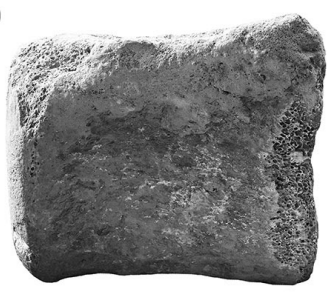

(g)

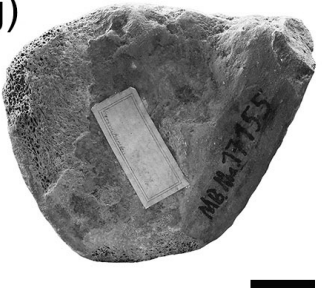

(h)

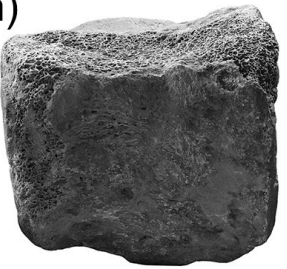

(l)
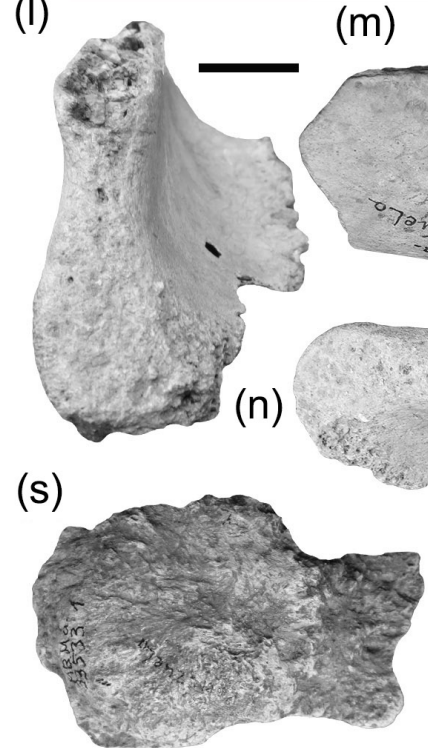

(t)

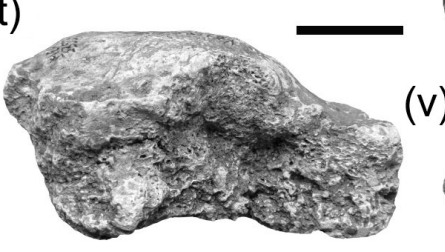

(m)

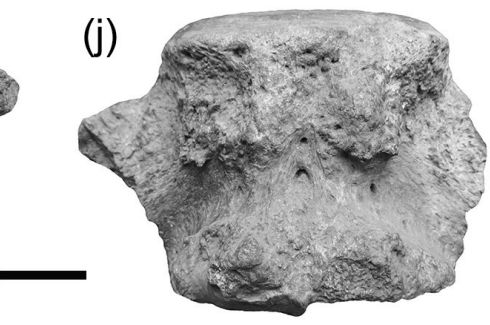

(k)

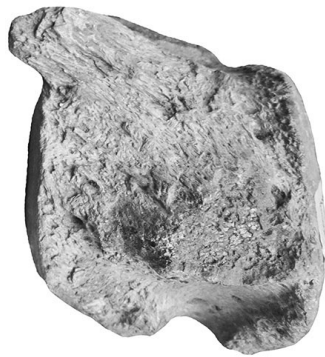

(o)

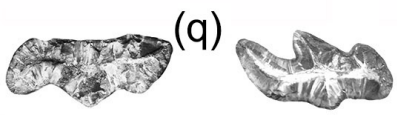

(p)

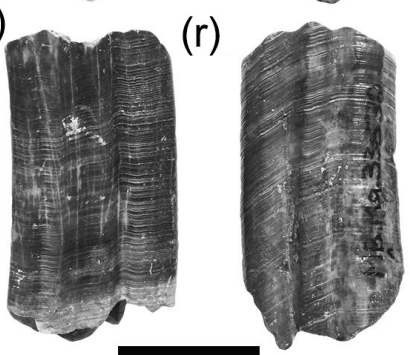

$(x)$
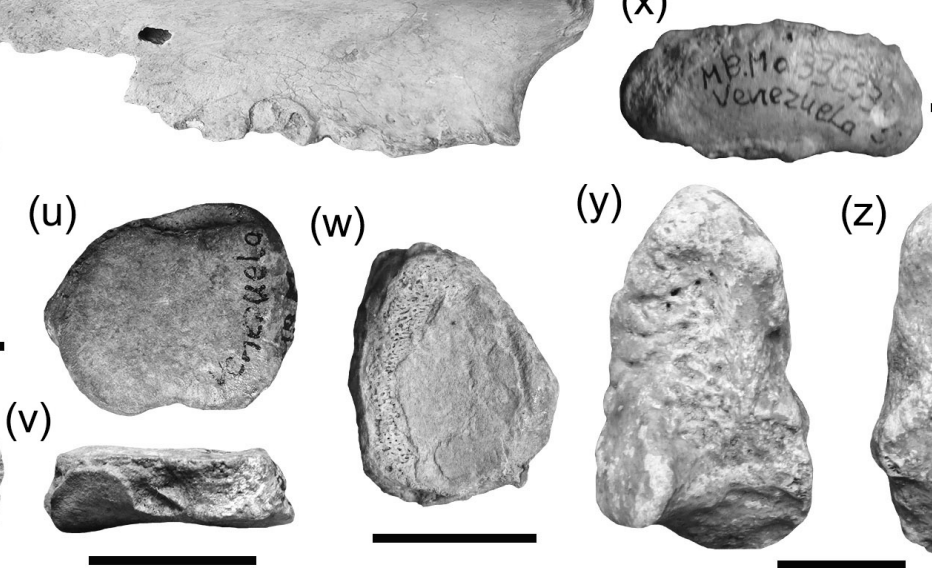

(w)

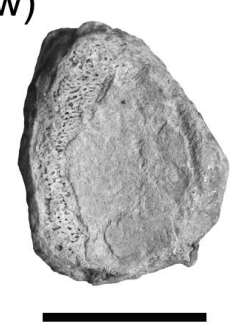

(y)

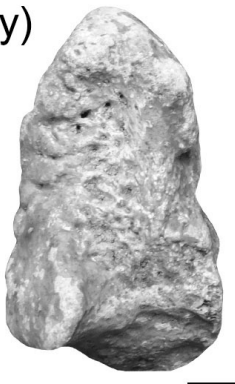

$(\mathrm{z})$

(z)

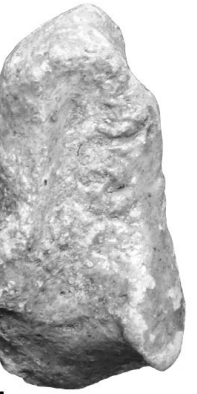

Figure 6. "Ground sloth" and glyptodont specimens. (a-k) Tardigrada indet. (a-h) Centra thoracic vertebrae ((a-b) MB.Ma. 17154; (c-d) MB.Ma. 17153; (e-f) MB.Ma. 17156; (g-h) MB.Ma. 17155); (i-k) centra of caudal vertebra (MB.Ma. 33543)], (l-r) Right hemimandible and two upper molariforms of Glyptotherium cf. G. cylindricum (MB.Ma. 33532), and (s-z) Glyptodontidae indet. [(s-t) osteoderm (MB.Ma. 33533-1); (u-z) four carpal-metacarpal elements of indet. laterality (MB.Ma. 33533-2-6). Scale bar equals $2 \mathrm{~cm}$. 
nostic characters in these elements precludes a more specific identification than Glyptodontidae indet.

\section{3 "South American native ungulates" (Notoungulata: Toxodontidae Gervais 1847)}

One possible tooth fragment referred in the MB.Ma. catalog as "Toxodonta" (MB.Ma. 33517) from San Juan de Los Morros (the specimen could not be located in the collection) and a postcranial element assigned to a pisiform (MB.Ma. 33542) of indeterminate laterality (Fig. 7a-d) from the Paraguaná Peninsula (Tables 1-2) are the only specimens assigned to this group in the $\mathrm{H}$. Karsten collection. The articular surfaces of the pisiform $(81.6 \mathrm{~mm}$ long) are slightly eroded. A comparison with some pisiforms of Toxodon Owen, 1837, from Argentina (MLP and PIMUZ) shows that the specimen from Venezuela is apparently much larger and robust. Mixotoxodon larensis Van Frank, 1957, is the only species known from the Pleistocene of Venezuela (Rincón, 2011; CarrilloBriceño, 2015), and its paleogeographic distribution possibly ranges from the United States to the north of Argentina (Carrillo-Briceño, 2015). Although dental characters have been used to distinguish Toxodon from Mixotoxodon (e.g., Van Frank, 1957; Rincón, 2011), little is known about their postcranial differences, especially for the few remains that have been assigned to Mixotoxodon. The absence of a stratigraphic context and of diagnostic characters in the specimen from Paraguaná Peninsula precludes a more specific identification than Toxodontidae indet.

\subsection{Proboscideans (Proboscidea: Gomphotheriidae Hay, 1922)}

The fossil specimens are represented only by four postcranial elements (Fig. 7e-o, Table 1); all of them were found in the "Barbacoas-Candelillas" locality, Colombia (Table 2). MB.Ma. 17152 corresponds to a thoracic vertebra that lacks the neural arch (Fig. 7e-g). Podial elements are represented by a left metacarpal II (MB.Ma. 17146; Fig. 7h-j), a right unciform (MB.Ma. 17147; Fig. 7k-m) and a right astragalus (MB.Ma. 17148; Fig. 7n-o). Recent taxonomic revisions of the South American gomphotheres, based on well-preserved diagnostic materials (e.g., upper tusks and/or complete skull elements), allowed the recognition of only two species, namely Cuvieronius hyodon Fischer, 1814, and Notiomastodon platensis Ameghino, 1888, with a distribution encompassing lowland to highland localities (Lucas, 2013; Mothé et al., 2013; Mothé and Avila, 2015). Some morphological distinctions have been observed in postcranial elements among North American and Neotropical gomphotheres (e.g., Ferretti, 2010; Lucas et al., 2011; Lucas, 2013). However, the lack of more detailed studies in postcranial bones of South American gomphotheres makes the identification of diagnostic features at generic or specific level difficult, especially if the specimens are not associated with other cranial elements such as mandibles, teeth and tusks (e.g., Mothé and Avila, 2015).

\subsection{Indeterminate mammalian remains}

Some specimens are only ascribed to Mammalia indet. due to their fragmentary nature (Figs. $7 \mathrm{p}-\mathrm{s}, 8$ ). They notably include what seems to be a fragment of the femoral head of a gigantic taxon (MB.Ma. 14109; Fig. 7r-s). While its maximum diameter reaches roughly $20 \mathrm{~cm}$, the proximal surface shows an irregular typical structure denoting an unfused epiphysis, indicating that the individual was not skeletally mature.

\section{Discussion}

\subsection{Implications and significance of Hermann Karsten's vertebrate collection}

According to Röhl (1944, p. 1004), the first mention of fossil vertebrate remains found by $\mathrm{H}$. Karsten dates from his exploration to the provinces of Caracas and Carabobo (trips made during his first journey to Venezuela between 1844 and 1847). Röhl (1944, p. 1004) noted that H. Karsten discovered remains of Megatherium in the vicinity of San Juan de Los Morros. In reference to this find, H. Karsten (1849, pp. 198-199) stated "Auf dem Rücken des östlichen Gebirgszuges findet sich eine Gruppe säulenartig hervorgehobener Kalkschichten mit dem darauf liegenden Sandsteine, die mit den in ihnen befindlichen Höhlen sehr an die früher von mir Ihnen beschriebenen und in Gesteinproben vorgelegten Kalkkegel von St. Juan de los Morros erinnern, in deren Umgebung gleichfalls fossile Reste des Megatherium's [sic] gefunden werden". Later in another publication (Karsten, 1886, p. 14), he wrote "A St. Juan on a trouvé dans ces marnes des squelettes de Megatherium [sic]". In both quotations above, H. Karsten does not claim the discovery of the Megatherium remains from San Juan de Los Morros; on the contrary, he emphasized that these remains "have been found there", so it is not clear if he found the fossil himself. The above is not an indication that $\mathrm{H}$. Karsten did not find remains of terrestrial sloths at San Juan de Los Morros; however, the only fossil specimens from this location attributable to the $\mathrm{H}$. Karsten collection that we could trace (fossils without a clear date of collection), are those assigned to Glyptotherium cf. G. cylindricum and Glyptodontidae indet. (Tables 1-2). Before the visit of H. Karsten to San Juan de Los Morros, remains referred to as Megatherium were also mentioned in this location by the naturalist and Venezuelan president José María Vargas Ponce and the renowned English artist and diplomat Sir Robert Ker Porter (Carrillo-Briceño, 2015, pp. 66-67). Fossils of Pleistocene "ground sloths" found in Venezuela during the 19th and the first half of the 20th century were referred to the southern closely related species Megatherium (e.g., Karsten, 1849, 
Table 2. Geographical context of fossil mammal specimens collected by H. Karsten.

\begin{tabular}{|c|c|c|c|c|c|}
\hline \multirow[t]{2}{*}{ Specimen number } & \multicolumn{2}{|l|}{ MN.Ma Catalog } & \multirow{2}{*}{$\begin{array}{l}\text { Historical provinces } \\
\text { during Karsten's travels }\end{array}$} & \multirow[t]{2}{*}{ Geographical region } & \multirow[t]{2}{*}{ Administrative entity } \\
\hline & Locality & Country & & & \\
\hline MN.Ma. 14109 & Barbacoas & $?$ & $?$ & $?$ & $?$ \\
\hline MN.Ma. 17145 & Barbacoas-Candelillas District & Colombia & Province of Barbacoas? & Pacific region? & Nariño Department? \\
\hline MN.Ma. 17146 & Barbacoas-Candelillas District & Colombia & Province of Barbacoas? & Pacific region? & Nariño Department? \\
\hline MN.Ma. 17147 & Barbacoas-Candelillas District & Colombia & Province of Barbacoas? & Pacific region? & Nariño Department? \\
\hline MN.Ma. 17148 & Barbacoas-Candelillas District & Colombia & Province of Barbacoas? & Pacific region? & Nariño Department? \\
\hline MN.Ma. 17149 & Barbacoas-Candelillas District & Colombia & Province of Barbacoas? & Pacific region? & Nariño Department? \\
\hline MN.Ma. 17150 & Barbacoas-Candelillas District & Colombia & Province of Barbacoas? & Pacific region? & Nariño Department? \\
\hline MN.Ma. 17151 & Barbacoas-Candelillas District & Colombia & Province of Barbacoas? & Pacific region? & Nariño Department? \\
\hline MN.Ma. 17152 & Barbacoas-Candelillas District & Colombia & Province of Barbacoas? & Pacific region? & Nariño Department? \\
\hline MN.Ma. 17153 & Barbacoas-Candelillas District & Colombia & Province of Barbacoas? & Pacific region? & Nariño Department? \\
\hline MN.Ma. 17154 & Barbacoas-Candelillas District & Colombia & Province of Barbacoas? & Pacific region? & Nariño Department? \\
\hline MN.Ma. 17155 & Barbacoas-Candelillas District & Colombia & Province of Barbacoas? & Pacific region? & Nariño Department? \\
\hline MN.Ma. 17156 & Barbacoas-Candelillas District & Colombia & Province of Barbacoas? & Pacific region? & Nariño Department? \\
\hline MN.Ma. 33532 & San Juan de Los Morros & Venezuela & Province of Caracas & Orinoquia region & Guárico State \\
\hline MN.Ma. 33533-1 & San Juan de Los Morros & Venezuela & Province of Caracas & Orinoquia region & Guárico State \\
\hline MN.Ma. 33533-2-6 & San Juan de Los Morros & Venezuela & Province of Caracas & Orinoquia region & Guárico State \\
\hline MB.Ma. 33517 & San Juan de Los Morros & Venezuela & Province of Caracas & Orinoquia region & Guárico State \\
\hline MN.Ma. 33534 & Barbacoas & Venezuela & Province of Barquisimeto & Andes & Lara State \\
\hline MN.Ma. 33535 & $?$ & Venezuela & ? & $?$ & $?$ \\
\hline MN.Ma. 33536 & Barbacoas & Venezuela & Province of Barquisimeto & Andes & Lara State \\
\hline MN.Ma. 33537 & Barbacoas & Venezuela & Province of Barquisimeto & Andes & Lara State \\
\hline MN.Ma. 33538 & Barbacoas & Venezuela & Province of Barquisimeto & Andes & Lara State \\
\hline MN.Ma. 33539 & Barbacoas & Venezuela & Province of Barquisimeto & Andes & Lara State \\
\hline MN.Ma. 33540 & Barbacoas & Venezuela & Province of Barquisimeto & Andes & Lara State \\
\hline MN.Ma. 33541 & Barbacoas & Venezuela & Province of Barquisimeto & Andes & Lara State \\
\hline MN.Ma. 33542 & Paraguaná Peninsula & Venezuela & Province of Coro & Caribbean region & Falcón State \\
\hline MN.Ma. 33543 & Barbacoas & Venezuela & Province of Barquisimeto & Andes & Lara State \\
\hline MN.Ma. 42896 & Barbacoas & Venezuela & Province of Barquisimeto & Andes & Lara State \\
\hline MN.Ma. 42897 & Barbacoas & Venezuela & Province of Barquisimeto & Andes & Lara State \\
\hline MN.Ma. 42899 & Barbacoas & Venezuela & Province of Barquisimeto & Andes & Lara State \\
\hline MN.Ma. 42900 & Barbacoas & Venezuela & Province of Barquisimeto & Andes & Lara State \\
\hline MN.Ma. 42901 & Barbacoas & Venezuela & Province of Barquisimeto & Andes & Lara State \\
\hline MN.Ma. 42902 & Barbacoas & Venezuela & Province of Barquisimeto & Andes & Lara State \\
\hline MN.Ma. 42903 & Barbacoas & Venezuela & Province of Barquisimeto & Andes & Lara State \\
\hline MN.Ma. 42904 & Barbacoas & Venezuela & Province of Barquisimeto & Andes & Lara State \\
\hline MN.Ma. 42905 & Barbacoas & Venezuela & Province of Barquisimeto & Andes & Lara State \\
\hline MN.Ma. 42906 & Barbacoas & Venezuela & Province of Barquisimeto & Andes & Lara State \\
\hline MN.Ma. 42907 & Barbacoas & Venezuela & Province of Barquisimeto & Andes & Lara State \\
\hline MN.Ma. 42908 & Barbacoas & Venezuela & Province of Barquisimeto & Andes & Lara State \\
\hline MN.Ma. 42909 & Barbacoas & Venezuela & Province of Barquisimeto & Andes & Lara State \\
\hline MN.Ma. 42910 & Barbacoas & Venezuela & Province of Barquisimeto & Andes & Lara State \\
\hline MN.Ma. 42911 & Barbacoas & Venezuela & Province of Barquisimeto & Andes & Lara State \\
\hline MN.Ma. 42935 & Barbacoas & Venezuela & Province of Barquisimeto & Andes & Lara State \\
\hline MN.Ma. 42936 & Barbacoas & Venezuela & Province of Barquisimeto & Andes & Lara State \\
\hline MN.Ma. 42937 & Barbacoas & Venezuela & Province of Barquisimeto & Andes & Lara State \\
\hline MN.Ma. 48085 & Barbacoas-Candelillas District & Colombia & Province of Barbacoas? & Pacific region? & Nariño Department? \\
\hline
\end{tabular}

1851, 1886; Nectario María, 1937, 1941; Schaub, 1935; Von der Osten, 1951). However, later taxonomic revisions (e.g., Cartelle and Iuliis, 1995) suggest that the previous assignations to Megatherium for specimens found in the region are erroneous, ascribing those specimens to Eremotherium (Cartelle and De Iuliis, 1995). Our own attributions go in the same direction.
In $1847 \mathrm{H}$. Karsten came back to Germany, and after one year (1848) returned to Venezuela to continue with his explorations; the Academy of Sciences in Berlin provided him with 300 thalers for paleontological excavations (Röhl, 1944). Megatherium remains from Barbacoas, Andes of Lara State (Karsten, 1849, p. 197), Carora (La Mesa, south Baragua River), Lara State (Karsten, 1851, p. 465) and the vicinity of Pueblo Nuevo, Paraguaná Peninsula, Fal- 
(a)

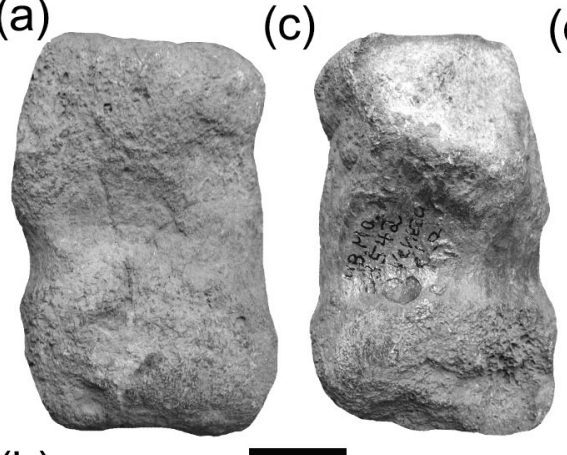

(b)
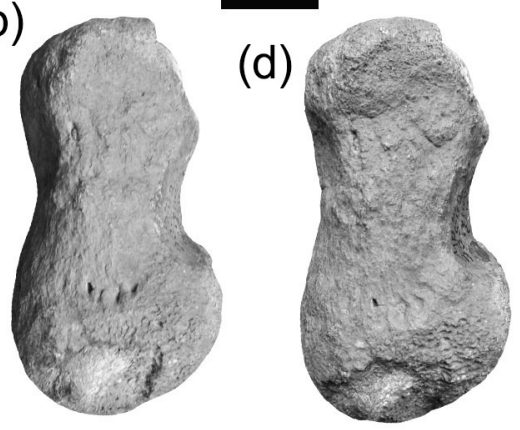

(e)

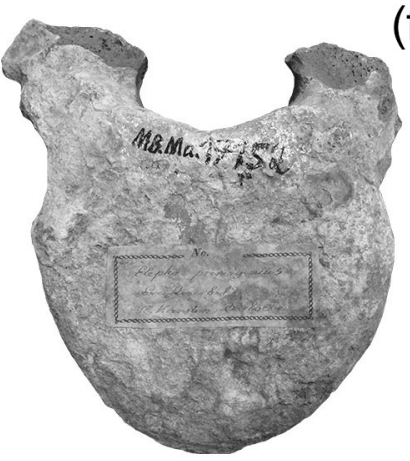

(h)

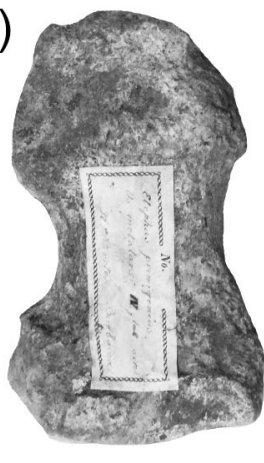

(f)

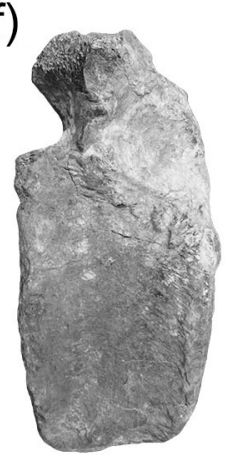

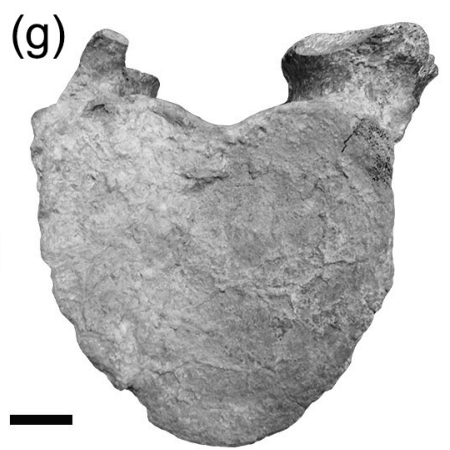

(j)

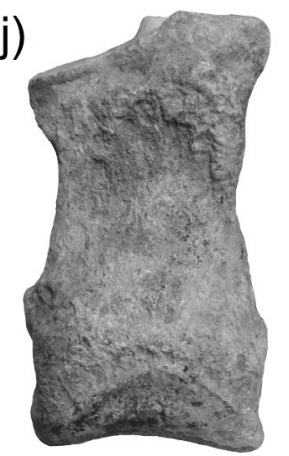

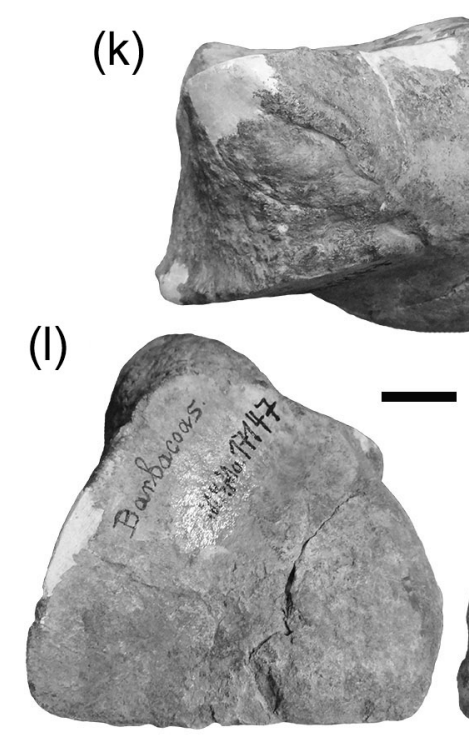
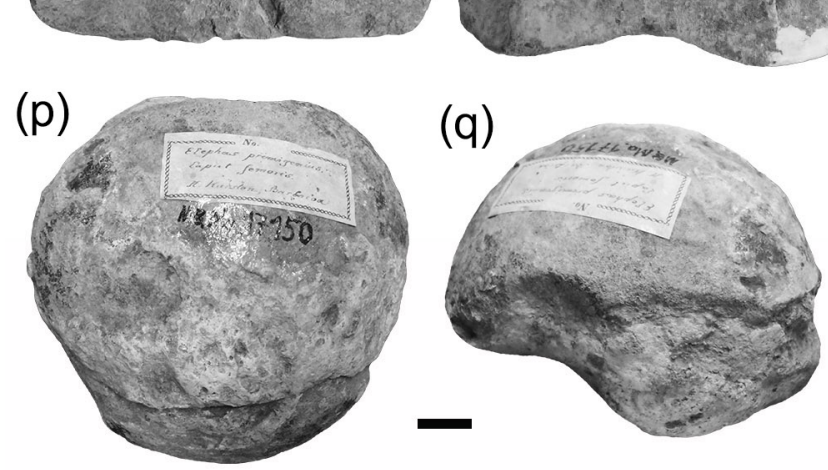

(r)

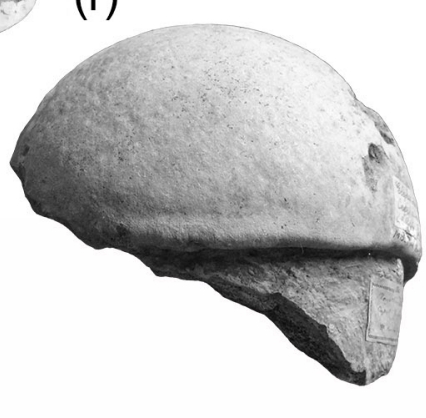

(o)

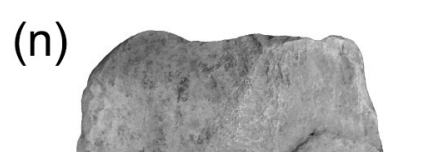

(i)

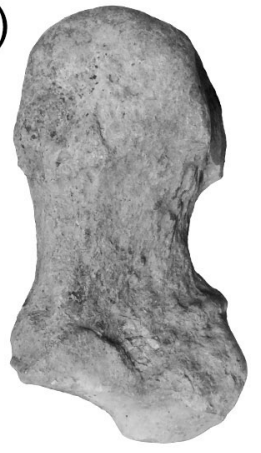

(m)
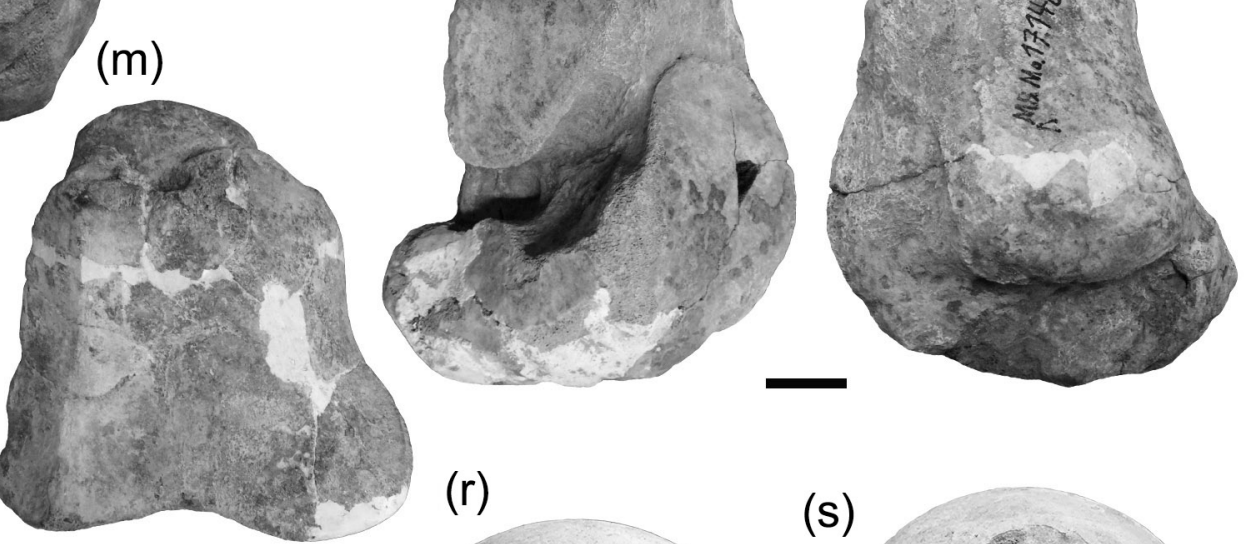

(s)

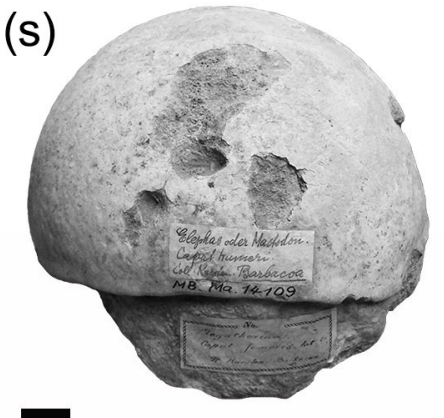

Figure 7. Notoungulata, proboscidean and mammalian indet. specimens. (a-d) Pisiform bone of Toxodontidae indet. (MB.Ma. 33542). (e-o) Gomphotheriidae indet.: (e-g) thoracic vertebra (MB.Ma. 17152); (h-j) left metacarpal II (MB.Ma. 17146); (k-m) right unciform (MB.Ma. 17147); (n-o) right astragalus (MB.Ma. 17148). (p-s) Mammalia indet.: (p-q) left humeral? head (MB.Ma. 17150); (r-s) femoral head (MB.Ma. 14109). Scale bar equals $2 \mathrm{~cm}$. 

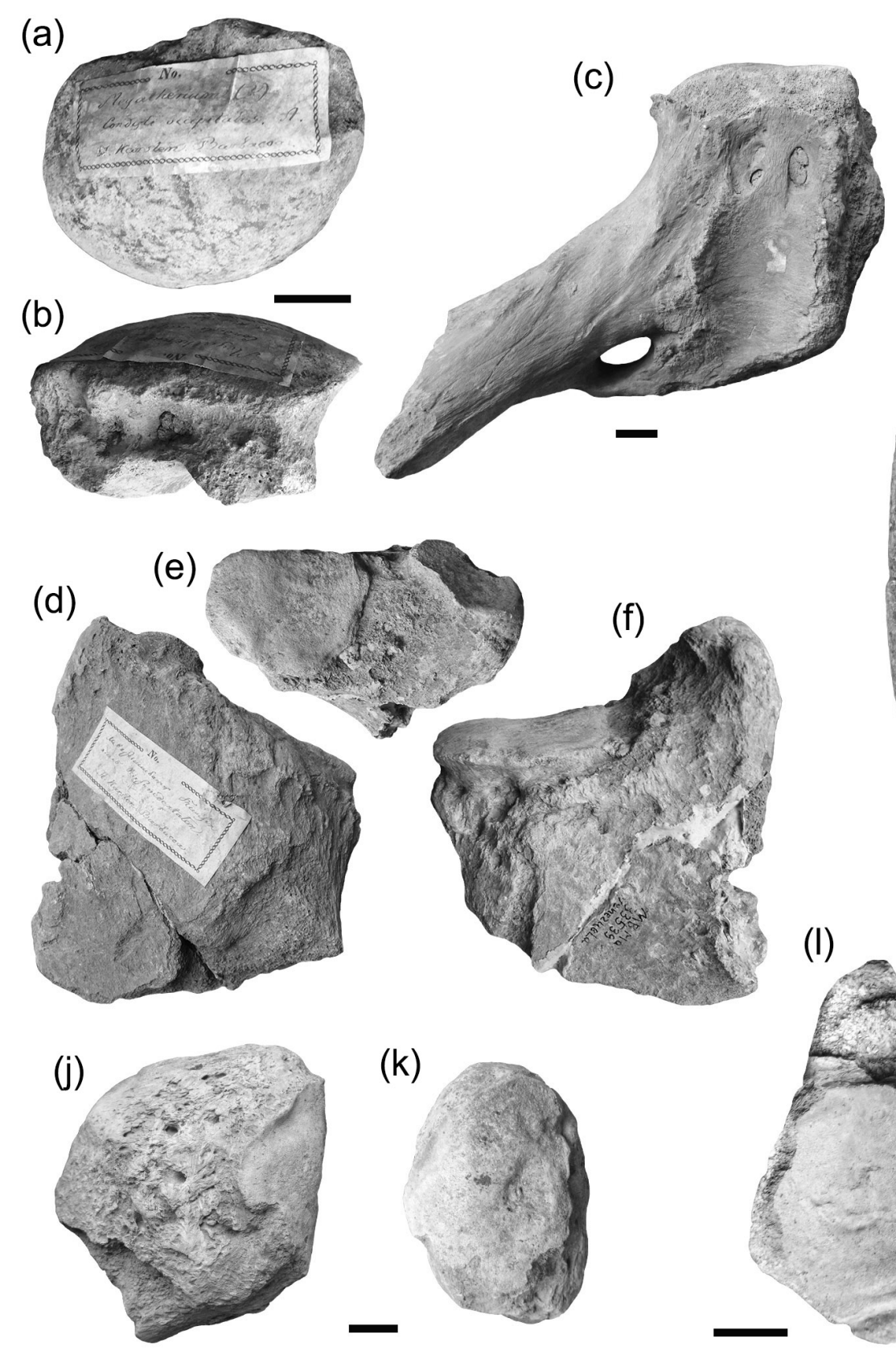

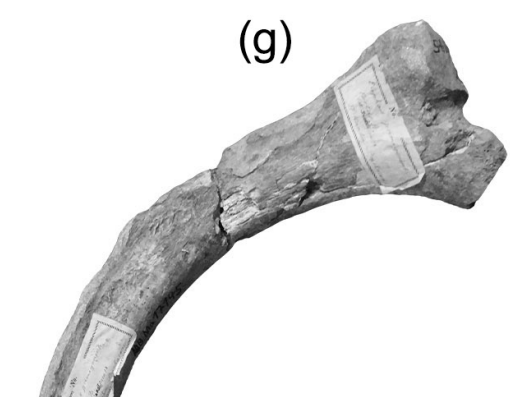

(i)

(h)

(I)
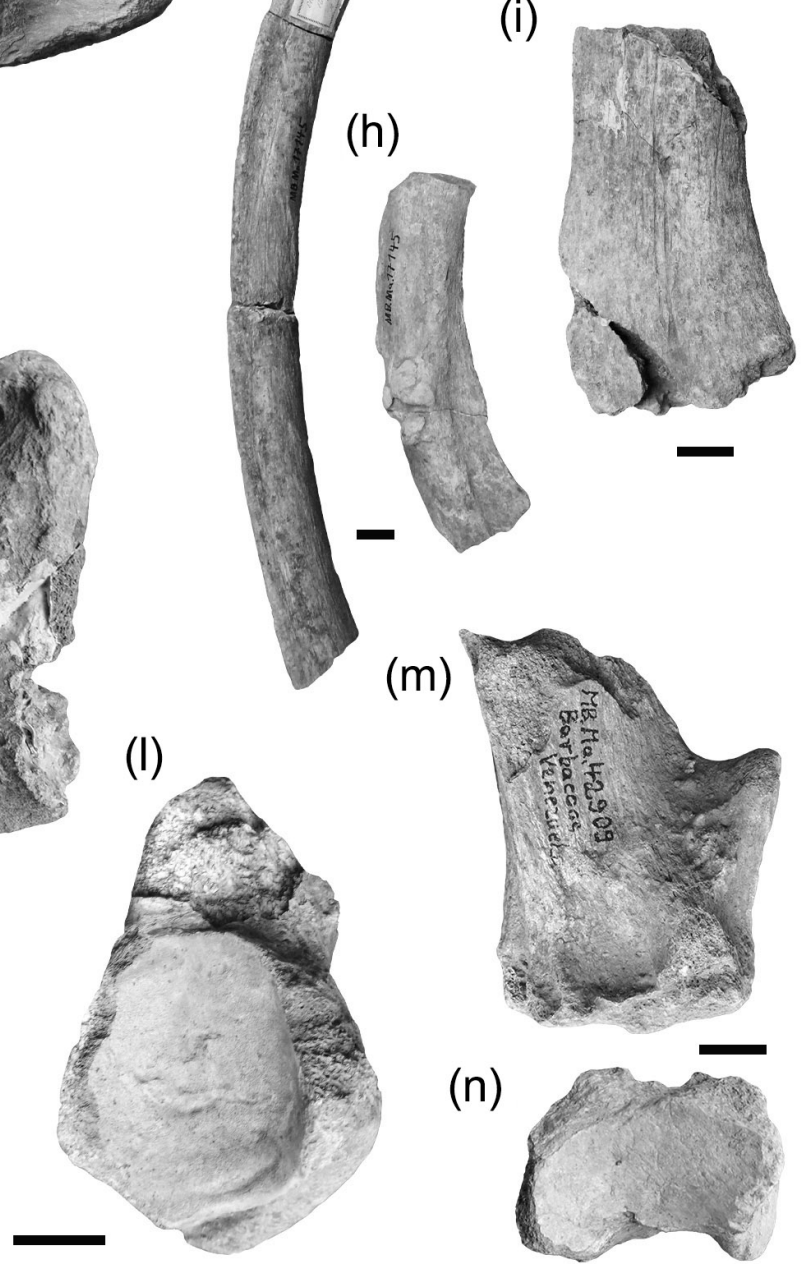

(n)
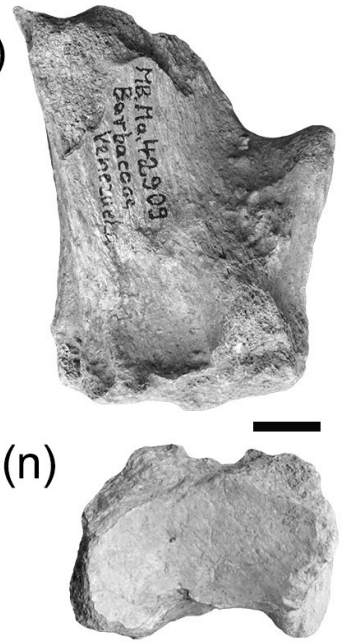

Figure 8. Mammalia indet. specimens. (a-b) Occipital condyle (MB.Ma. 42899); (c) fragment of sacral vertebra (MB.Ma. 42908); (d-f) indet. fragment of postcranial element (MB.Ma. 33539); (g-i) dorsal rib fragments (MB.Ma. 17145, MB.Ma. 17149); and (j-k) fragments of indet. postcranial elements (MB.Ma. 42909, MB.Ma. 42910, MB.Ma. 42911). Scale bar equals $2 \mathrm{~cm}$.

cón State (Karsten, 1851, p. 467), were referred to. Possible "ground sloth" remains were also found by H. Karsten in Cerro Turimiquire, Sucre State, western Venezuela (Karsten, 1859b, p. 292; 1886, p. 11). H. Karsten (1851, p. 467) stated that years before his visit to Pueblo Nuevo (Paraguaná Peninsula), some locals discovered a complete fossil skeleton of an enormous mammal while drilling a well. According to the locals, the femur was 4.5 feet long $(\sim 106 \mathrm{~cm})$ with a head diameter of 1 foot $(\sim 30.4 \mathrm{~cm})$. H. Karsten mentioned that abundant fossil remains of mammals, among which he recognized Megatherium (Karsten, 1851, p. 467), were found at San José de Cúcuta (Colombia), close to the Venezuelan border in the Andean region (Táchira State).

The Megatheriidae, Mylodontidae and Tardigrada indet. remains described here from the $\mathrm{H}$. Karsten collection (Tables 1-2) include specimens from just one location in 
Venezuela and one in Colombia. The Venezuelan location mentioned on the labels is Barbacoas, and we did not find any specimens from the other Venezuelan locations (Carora, Paraguaná Peninsula and Cerro Turimiquire) mentioned by H. Karsten (Karsten, 1851, pp. 465, 467; 1859b, p. 292; 1886 , p. 11). There are no vertebrate specimens labeled as being from the Colombian sites of San José de Cúcuta (Karsten, 1851, p. 467) or El Plato (Karsten, 1886, p. 49). The only specimens from Colombia in the H. Karsten collection are those labeled as from "Barbacoas-Candelillas District, Kolumbien" (Table 2). We did not find a mention of the latter location in any of the relevant publications (Karsten, 1853, 1858, 1859a, 1886), and, as mentioned above, "Barbacoas-Candelillas District" may have been part of the former province of Barbacoas, which existed from 1846 to 1855 , in the Republic of New Granada (nowadays Nariño Department, southern Colombia). Although it is unknown whether H. Karsten visited this location, it is recorded that on his trip he visited many places in its vicinity (e.g., Karsten, 1886, pp. 1-2, 22-35). Karsten (1886, p. 49) stated about his fossil vertebrate find from Colombia "toutes les peines que je pris pour en déterrer quelques-uns des mieux conservés, dans un but scientifique, furent rendues vaines par la fragilité des ossements; je ne dressai pas même de liste exacte de ces localités, tant elles étaient nombreuses, de sorte que je ne puis malheureusement donner maintenant qu'une partie de celles que j'ai connues". Due to the unclear information in H. Karsten's publications and in the catalog data, it is not possible to establish with certainty the provenance of many fossil vertebrates. After more than 160 years, problems associated with labels/classification and/or destruction and damage of collections, especially during the Second World War, could have affected valuable information and even the final whereabouts of some "missing" H. Karsten fossils. It is possible that $\mathrm{H}$. Karsten did not collect all the fossil vertebrates he referred to, as was noted by himself (e.g., Karsten, 1886, p. 49).

Many historical and geological/paleontological publications, especially about Venezuela, have mentioned $H$. Karsten's fossil vertebrate finds in a repetitive manner and sometimes with incorrect taxonomic and provenance information (e.g., Jahn, 1921, p. 39; Liddle, 1928, p. 351; Schaub, 1935, p.1; Von der Osten, 1947, p. 161; Takacs et al., 1967 or 1968, p. 32; Linares, 1983, p. 1; Ochsenius, 1980, p. 21; Rincón et al., 2006, p. 530, 2008, p. 197; Rincón and White, 2007, p. 2; Carrillo-Briceño et al., 2008, p. 242; Rincón, 2011 , p. 894). In a detailed revision of H. Karsten's bibliography (e.g., Karsten, 1849, 1850a, b, 1851, 1862, 1886), we have not been able to find any mention of or reference to fossil remains of glyptodonts, toxodonts, proboscideans or horses, from Barbacoas (Lara State) or any other locality of Colombia or Venezuela, contrary to reports by Jahn (1921, p. 39), Liddle (1928, p. 351), Schaub (1935, p. 1), Von der Osten (1947, p. 161), Takacs et al. (1967, p. 32), Linares (1983, p. 1), Ochsenius (1980, p. 21), Rincón et al.
(2006, p. 530, 2008, p. 197), Rincón and White (2007, p. 2), Carrillo-Briceño et al. (2008, p. 242), and Rincón (2011, p. 894). For example, Jahn (1921, p. 39) stated "En las arcillas sedimentarias de Barbacoas descubrió Karsten en 1850 restos fósiles de Taxodon [sic], Gliptodon [sic], Mastodon y una especie de equino que se diferencia bastante, en cuanto a su dentadura, del Equus Andium [sic] del Ecuador". The reference of Jahn (1921, p. 39) has possibly given rise to the use of this erroneous information in a repetitive manner by Liddle $(1928$, p.351) and other subsequent publications. The new taxonomic list presented herein securely documents the existence of "South American ungulates", "ground sloths", glyptodonts and proboscidean remains in the H. Karsten collection (MB.Ma.); however, their provenance is unclear. The H. Karsten vertebrate collection lacks a clear stratigraphic/age context; nevertheless, none of the specimens are well mineralized, having a typical Pleistocene type of preservation. From the overall H. Karsten vertebrate collection, the "ground sloth" remains are the most abundant. As is to be expected, the widely distributed species $E r$ emotherium laurillardi (Cartelle and De Iuliis, 1995) is represented in the collection. The rest of the "ground sloths," together with the Toxodontidae and Gomphotheriidae specimens, do not offer significant information regarding biostratigraphy and biogeography, due to the fragmentary nature and scarce diagnostic characters of the specimens. In contrast, the presence of Glyptotherium cf. G. cylindricum from San Juan de Los Morros (Orinoco River basin) increases the paleobiogeographic range of this taxon because to date Glyptotherium remains have only been recorded in South America in a few lowland Late Pleistocene localities of the Caribbean basin in Venezuela (Carlini et al., 2008; Carlini and Zurita, 2010) and the Atlantic coast of Brazil up to $20^{\circ} \mathrm{S}$ (Oliveira et al., 2010). According to Zurita et al. (2012), Glyptotherium records from Venezuela and Brazil suggest that after its entry into South America during the Great American Biotic Interchange (GABI), this taxon could have followed an "eastern corridor" as a migratory route. Below the $20^{\circ} \mathrm{S}$, the only recorded Glyptodontinae corresponds to Glyptodon, which is also recorded in a strip parallel to the Cordillera de Los Andes (Zurita et al., 2012).

\section{Conclusions}

Hermann Karsten is well known due to his various contributions to botany in South America during the second part of the 19th Century. His explorations allowed him to produce important geographic and geologic descriptions that make him a pioneer in these topics as well. Although the H. Karsten collections from South America are found in different museums and botanical gardens of Europe (e.g., extant plants and some fossil invertebrates), we have not found references to vertebrate fossil specimens deposited in any other collection apart from the Museum of Natural History 
in Berlin. For more than 160 years, this vertebrate collection was practically unknown and subject to incorrect taxonomic and provenance references. Many of H. Karsten's vertebrate fossils are broken and incomplete, which prevented us from undertaking a more accurate taxonomic identification for specimens of Mylodontidae, Toxodontidae and Gomphotheriidae, with the exception of the "ground sloth" Eremotherium laurillardi. However, the identification of Glyptotherium cf. G. cylindricum from San Juan de Los Morros (Orinoco River basin) increases the paleobiogeographic range of this taxon, which has been previously referred to from a few coastal locations in Venezuela and Brazil. Using H. Karsten's publications and his fossil collection, we can suggest that fossil remains attributable to horses were not found by him during his expeditions, contrary to claims in many publications from the 19th and 20th century. The $\mathrm{H}$. Karsten vertebrate collection was one of the first made during a scientific exploration in Venezuela and the Nueva Granada and is thus of historical importance for the paleontology of the region.

\section{Data availability}

The data presented are based purely on fossil specimens, which are designated by a specific catalog number. All the fossil specimens used here are available in their entirety in a public repository: the fossil vertebrate collection of the Museum für Naturkunde in Berlin (MB.Ma.). Access to the collection is obtained by a request directly to the curator of the collection and the relevant authorities. All relevant data necessary to replicate the results presented in our article are available in this paleontological collection.

Acknowledgements. This work was supported by the Swiss National Science Foundation SNF grant 31003A-149605 to Marcelo Ricardo Sánchez-Villagra and by an Alexander von Humboldt fellowship granted to Eli Amson. The authors wish to express their gratitude to Oliver Hampe and Dieter Korn (Museum für Naturkunde) for all the support and for permission to study the Hermann Karsten Collection. We thank Analía Forasiepi, Hyram Moreno, Loic Costeur, Imerú Alfonzo Hernández, Camilo Morón, Christian Klug, Pedro Rivas, Marcelo Reguero, Stephan Spiekman, Christine Argot, Brenda Ferrero, Omar Recabarren, Dimila Mothé and Juan David Carrillo for their generous and important advice and collaboration. We thank the Universidad Experimental Francisco de Miranda, Museo de Ciencias de Caracas, Universidad Central de Venezuela, Palaeontological Institute and Museum at the University of Zurich, Natural History Museum of Basel, Muséum national d'Histoire naturelle (Paris) and Museo de La Plata, for access to comparative material. We greatly appreciated comments and suggestions from the reviewers Alfredo Carlini, Spencer G. Lucas and to the Copernicus editorial team.

Edited by: F. Witzmann

Reviewed by: A. A. Carlini andS. G. Lucas

\section{References}

Aalto, K. R.: Hermann Karsten, pioneer of geologic mapping in northwestern South America, Hist. Geo Space. Sci., 6, 57-63, doi:10.5194/hgss-6-57-2015, 2015.

Alert, A.: Bajo los trópicos, Hermann Karsten y Franz Engel en América del Sur, in: Alemanes en las Regiones Equinocciales: Libro Homenaje al Bicentenario de la Llegada de Alexander von Humboldt a Venezuela, 1799-1999, edited by: Rodríguez, J. A., Alfadil Ediciones, Caracas, Venezuela, 142-160, 1999.

Ameghino, F.: Rápidas diagnosis de algunos mamíferos fósiles nuevos de la República Argentina, Obras Completas, Buenos Aires, 5, 469-480, 1888.

Brown, B.: Brachyostracon, a new genus of glyptodonts from México, Bull. Am. Mus. Nat. Hist., 31, 167-177, 1912.

Carlini, A. A. and Zurita, A. E.: An introduction to Cingulate evolution and their evolutionary history during the Great American Biotic Interchange: biogeographical clues from Venezuela, in: Urumaco and Venezuelan Paleontology, edited by: Sánchez-Villagra, M. R., Aguilera, O. A., and Carlini, F., Indiana Press University, Bloomington, 233-255, 2010.

Carlini, A. A., Zurita, A. E., and Aguilera, O. A.: North American Glyptodontines (Xenarthra, Mammalia) in the Upper Pleistocene of northern South America, Paläont. Z., 82, 125-138, doi:10.1007/BF02988404, 2008.

Carrillo-Briceño, J. D.: Bestias Prehistóricas de Venezuela "Colosos de la Edad de Hielo", Río Verde, Caracas, 287 pp., 2015.

Carrillo-Briceño, J. D., Chávez, A. E., and Alfonso, H. I.: Notas preliminares sobre los mastodontes gonfoterios (Mammalia: Proboscidea) del Cuaternario venezolano, Boletín Antropológico, 26, 233-266, 2008.

Cartelle, C. and De Iuliis, G.: Eremotherium laurillardi: the panamerican late Pleistocene megatheriid sloth, J. Vert. Paleontol., 15, 830-841, doi:10.1080/02724634.1995.10011265, 1995.

De Loriol, P.: Note sur quelques espèces nouvelles appartenant à la classe des Échinodermes, Mem. Soc. Phys. Hist. Nat. Geneve., 24, 659-673, 1874-1876.

Ferretti, M. P.: Anatomy of Haplomastodon chimborazi (Mammalia, Proboscidea) from the late Pleistocene of Ecuador and its bearing on the phylogeny and systematics of South American gomphotheres, Geodiversitas, 32, 663-721, 2010.

Fischer, G.: Zoognosia tabulis synopticis illustrata, Typis Nicolai Sergeidis Vsevolozsky, Moscow, 3, 1-694, 1814.

Gervais, F. L. P.: Observations sur les mammifères fossiles du midi de la France, Deuxième partie, Annls. Sci. Nat. (Zoologie), 8, 203-224, 1847.

Hay, O. P.: Further observations on some extinct elephants, Proc. Biol. Soc. Wash., 35, 97-102, 1922.

Hedberg, H. D.: Hermann Karsten, Pioneer geologist in northern South America, 1844-1856, Verh. Naturforsch. Ges. Basel, 84, 32-44, 1974.

Jahn, A.: Esbozo de las formaciones geológicas de Venezuela, Litografía del Comercio, Caracas, 108 pp., 1921.

Karsten, H.: Über die Geologie von Venezuela, Ber. Akad. Wiss. Berlin, (im Monat Juli 1849), 197-200, 1849.

Karsten, H.: Herr Hermann Karsten and Herrn Beyrich, Cumaná den 23, März 1850, Z. Dtsch. Geol. Ges., 2, 86-88, 1850a.

Karsten, H.: Beitrag zur Kenntniss der Gesteine des nördlichen Venezuela, Z. Dtsch. Geol. Ges., 2, 345-361, 1850 b. 
Karsten, H.: Über die geognostischen Verhältnisse der nördliche Venezuela, Arch. Mineral. Geogn. Bergbau Hüttenkd., 24, 440479, 1851.

Karsten, H.: Geognostische Bemerkungen über die Umgebungen von Maracaybo und über die Nordküste von Neu-Granada, Arch. Mineral. Geogn. Bergbau Hüttenkd., 25, 567-573, 1853.

Karsten, H.: Über die geognostischen Verhältnisse des westlichen Columbien, der heutigen Republiken Neu-Granada und Equador, Amtliche Berichte, Über die Zwei und Dreissigste Versammlung, Deutscher Naturforscher und Ärzte, zu Wien im September 1856, 32, 80-117, 1858.

Karsten, H.: Ueber einige Versteinerungen der Kreideformation aus New-Granada, Z. Dtsch. Geol. Ges., 11, 473-474, 1859a.

Karsten, H.: Reisenotizen über die Provinz Cumana in Venezuela, Westermann's illustrierte deutsche Monatshefte, 7, 282-298, $1859 \mathrm{~b}$

Karsten, H.: Die geognostische Beschaffenheit der Gebirge der Provinz Caracas, Z. Dtsch. Geol. Ges., 14, 282-287, 1862.

Karsten, H.: Géologie de L'ancienne Colombie Bolivarienne: Vénézuela, Nouvelle-Grenade et Ecuador, Berlin, R. Friedländer \& Sohn, 62 pp., 1886.

Latham, J. and Davies, H.: Faunula indica. Appendix to Forster, J. R., Zoologia indica Ed. secunda, Halae Ad Salam, 38 pp., 1795.

Liddle, R. A.: The geology of Venezuela and Trinidad, J. P. MacGowan, Fort Worth, Texas, 552 pp., 1928.

Linares, O. J.: Mamíferos fósiles del Pleistoceno de Venezuela, Museo Arqueológico de Quíbor-Fundacultura, Quíbor, Venezuela, 17 pp., 1983.

Lucas, S. G., Aguilar, R. H., and Spielmann, J. A.: Stegomastodon (Mammalia, Proboscidea) from the Pliocene of Jalisco, Mexico and the species-level taxonomy of Stegomastodon, New Mexico Museum of Natural History and Science Bulletin, 53, 517-553, 2011.

Lucas, S. G.: The palaeobiogeography of South American gomphotheres, J. Palaeogeogr., 2, 19-40, 2013.

Lund, P. W.: Blyk paa Brasiliens Dyreverden før den Sidste Jordomvaeltning, Fjerde Afhandling: Fortsættelse af Pattedyrene, Det Kongelige Danske Videnskabernes Selskbas Naturvidenskabelige og Mathematiske Afhandlinger, 9, 137-208, 1842.

Mothé, D. and Avilla, L.: Mythbusting evolutionary issues on South American Gomphotheriidae (Mammalia: Proboscidea), Quaternary Sci. Rev., 110, 23-35, doi:10.1016/j.quascirev.2014.12.013, 2015.

Mothé, D., Avilla, L. S., and Cozzuol, M. A.: The South American Gomphotheres (Mammalia: Proboscidea): taxonomy, phylogeny, and biogeography, J. Mammal. Evol., 20, 23-32, doi:10.1007/s10914-012-9192-3, 2013.

Nectario María, H.: Los grandes mamíferos fósiles de la región de Barquisimeto, Boletín de Geología y Minería, 1, 301-317, 1937.

Nectario María, H.: El Megatherium larensis de Venezuela, Rev. Geog. Amer., 16, p. 6, 1941.

Ochsenius, C.: Cuaternario en Venezuela: Introducción a la paleoecología en el norte de Sudamérica, Universidad Nacional Experimental Francisco de Miranda, Coro, Venezuela, 68 pp., 1980.
Oliveira, É. V., Porpino, K. O., and Barreto, A. F.: On the presence of Glyptotherium in the Late Pleistocene of Northeastern Brazil, and the status of "Glyptodon" and "Chlamydotherium", Paleobiogeographic implications, N. Jb. Geol. Paläont., Abh., 258, 353-363, doi:10.1127/0077-7749/2010/0116, 2010.

Osborn, H. F.: Glyptotherium texanum, a new glyptodont from the lower Pleistocene of Texas, Bull. Am. Mus. Nat. Hist., 19, 491494, 1903.

Owen, R.: A description of the Cranium of the Toxodon Platensis, a gigantic extinct mammiferous species, referrible by its dentition to the Rodentia, but with affinities to the Pachydermata and the Herbivorous Cetacea, Proc. Geol. Soc. Lond., 2, 541-542, 1837.

Owen, R.: Description of a tooth and part of the skeleton of the Glyptodon, a large quadruped of the edentate order, to which belongs the tessellated bony armour figured by Mr. Clift in his memoir on the remains of the Megatherium, brought to England by Sir Woodbine Parish, F.G.S., Proc. Geol. Soc. Lond., 3, 108$113,1839$.

Rincón, A. D.: New remains of Mixotoxodon larensis Van Frank 1957 (Mammalia: Notoungulata) from Mene de Inciarte Tar Pit, north-western Venezuela, Interciencia, 36, 894-899, 2011.

Rincón, A. D. and White, R. S.: Los Xenarthra Cingulata del Pleistoceno Tardío (Lujanense) de Cerro Misión, estado Falcón, Venezuela, Boletín de la Sociedad Venezolana de Espeleología, 41, 2-12, 2007.

Rincón, A. D., Alberdi, M. T., and Prado, J. L.: Nuevo registro de Equus (Amerhippus) santaeelenae (Mammalia, Perissodactyla) del pozo de asfalto de Inciarte (Pleistoceno Superior) de Venezuela, Ameghiniana, 43, 529-538, 2006.

Röhl, E.: Hermann Karsten, 1817-1908: Dr. Fil. y Med. y Prof. de Botánica. 1817-1908, Boletín de la Academia de Ciencias Físicas, Matemáticas y Naturales, Año 10, 8, 991-1027, 1944.

Schaub, S.: Säugetierfunde aus Venezuela und Trinidad, Schweiz, Palaeontol. Abh., 55, 1-21, 1935.

Takacs, F., Peñalver, H. G., and de Díaz Ungría, A. G.: Investigaciones paleontológicas, Boletín del Instituto de Antropología e Historia Estado Carabobo, 2, 27-37, 1967.

Tryon, A. F.: Hermann Karsten, His Collections and the Flora Columbiae, Taxon, 12, 103-105, 1963.

Van Frank, R.: A fossil collection from northern Venezuela. I. Toxodontidae (Mammalia: Notoungulata), Am. Mus. Novit., 1850, 1-38, 1957.

von Buch, L.: Die Anden in Venezuela, Z. Dtsch. Geol. Ges., 2, 339-345, 1850.

Von der Osten, E.: Resumen de la paleontología vertebrada de Venezuela, Mem. Fund. La Salle Cien. Nat, 19, 153-170, 1947.

Von der Osten, E.: Megatherium venezuelensis n. sp. Un nuevo megaterio procedente del Estado Lara, Ministerio de Minas e Hidrocarburos, Boletín de Geología, 1, 229-234, 1951.

Zurita, A. E., Mino-Boilini, A. R., Francia, A., and ArenasMosquera, J.: The Pleistocene Glyptodontidae Gray, 1869 (Xenarthra: Cingulata) of Colombia and some considerations about the South American Glyptodontinae, Rev. Bras. Paleontol., 15, 273-280, doi:10.4072/rbp.2012.3.04, 2012. 